\title{
Driving Factors for Isoprene-Surface Ozone and Carbon Dioxide Chemistry Over an Oil Palm plantation in Malaysia
}

mohd shahrul mohd nadzir ( $\sim$ shahrulnadzir@ukm.edu.my )

Universiti Kebangsaan Malaysia https://orcid.org/0000-0003-0925-3998

Maggie Chel Gee Ooi

Universiti Kebangsaan Malaysia Fakulti Sains dan Teknologi

Neil RP Harris

Cranfield University

Conor Bolas

University of Cambridge

Sherin Hassan Bran

National Astronomical Research Institute of Thailand

Ronald C Macatangay

National Astronomical Research Institute of Thailand

Andy Chan

Nottingham University Malaysia Campus

Yit Arn Teh

The University of Newcastle - Newcastle City Campus

Wan Shafrina Wan Mohd Jaafar

Universiti Kebangsaan Malaysia

Yusri Yusup

Universiti Sains Malaysia

Mohd Talib Latif

Universiti Kebangsaan Malaysia

Md Firoz Khan

Universiti Malaya

Fatimah Ahamad

Universiti Kebangsaan Malaysia

Lip Khoon Kho

Malaysian Palm Oil Board

A'fifah Abd Razak

Malaysian Palm Oil Board

Nur Maisarah Jantan 
Malaysian Palm Oil Board

\section{Yahaya Hawari}

Malaysian Palm Oil Board

Ahmad Norazhar Mohd Yatim

Universiti Malaysia Sabah

Haris Hafizal Abd Hamid

Universiti Kebangsaan Malaysia

Khairul Nizam Abdul Maulud

Universiti Kebangsaan Malaysia

Muhammad Ikram A Wahab

Universiti Kebangsaan Malaysia

Mazrura Sahani

Universiti Kebangsaan Malaysia

Asnor Azrin Sabuti

International Islamic University Malaysia

Mohd Fadzil Firdzaus Mohd Nor

Universiti Malaya

Noratiqah Mohd Ariff

Universiti Kebangsaan Malaysia

Mohd Aftar Abu Bakar

Universiti Kebangsaan Malaysia

Badrul Hisyam Zainudin

Lembaga Koko Malaysia

Lin Chin Yik

Universiti Malaya

\section{Research}

Keywords: Isoprene, surface ozone, carbon dioxide and Elaeis guineensis

Posted Date: August 27th, 2020

DOI: https://doi.org/10.21203/rs.3.rs-56420/v1

License: (c) (1) This work is licensed under a Creative Commons Attribution 4.0 International License. Read Full License 


\section{Abstract}

Background: Biogenic Volatile Organic Compounds (BVOCs) such as isoprene $\left(\mathrm{C}_{5} \mathrm{H}_{8}\right)$ are ozone $\left(\mathrm{O}_{3}\right)$ precursors that can be emitted at significant concentrations from the oil palm tree (Elaeis guineensis). Reactions involving BVOCs can lead to increased levels of surface $\mathrm{O}_{3}$ which can significantly impair air quality and cause crop damage. This study focuses on the link between isoprene, surface $\mathrm{O}_{3}$ and carbon dioxide $\left(\mathrm{CO}_{2}\right)$ over an oil palm plantation and the effects of meteorological factors such as temperature and irradiance on the gas concentrations. The mixing ratios of isoprene, surface $\mathrm{O}_{3}$ and $\mathrm{CO}_{2}$ were measured using a portable gas chromatograph with a photoionization detector called 'iDirac', an EcoTech $\mathrm{O}_{3}$ analyser, and LI-COR, respectively. Atmospheric models were used for measured selected gases estimation and validation purposes.

Results: Results showed that isoprene and surface $\mathrm{O}_{3}$ had maximum daytime mixing ratios of $\sim 25 \mathrm{ppb}$ and $\sim 57 \mathrm{ppb}$, respectively. $\mathrm{CO}_{2}$ mixing ratios were high during the night compared to the day, with a maximum night-time ratio of $\sim 883 \mathrm{ppm}$. It is also showed that suppression of isoprene emissions from plants by high $\mathrm{CO}_{2}$ concentrations during the night was due to the reduction of dimethylallyl diphosphate (DMADP) in the leaf cells. The meteorological parameters temperature and light intensity were significantly correlated with isoprene and surface $\mathrm{O}_{3}$, with $r^{2}=0.91$ and $p<0.01$ and $r^{2}=0.87$ and $p<0.01$, respectively. The Model of Emissions of Gases and Aerosol from Nature (MEGAN) estimated emission rates of isoprene from the oil palm plantation are in the range $\sim 5000$ to $\sim 7000 \mathrm{\mu gm}^{-2} \mathrm{~h}^{-1}$ which are higher than previous studies on pristine forest. This information together with the the in-situ measurement information on isoprene emission flux is then fed into the WRF-CMAQ atmospheric chemistry model to study the effect of oil palm plantation expansion over the years $(2000-2016)$ on the local atmospheric chemistry.

Conclusions: The in-situ of isoprene measurement in oil palm plantation has provided the variations of atmospheric concentration at different time scale which is important in giving information of surface $\mathrm{O}_{3}$ production. The relationship between isoprene-surface $\mathrm{O}_{3}$ and $\mathrm{CO}_{2}$-isoprene were interconnected at different time and influenced by meteorological factors. The model has discovered regions that are converted into oil palm plantation has experienced rise in isoprene concentration in region that are converted into oil palm plantation, and it even can be carried downwind up to $100 \mathrm{~km}$ inland of the emission source.

\section{Background}

Over 70 different Biogenic Volatile Organic Compounds (BVOCs) are known to be emitted by plants [1, 2, $3,4,5,6]$. BVOCs contribute about $90 \%$ of all VOCs in the atmosphere [7]. Of these, isoprene $\left(\mathrm{C}_{5} \mathrm{H}_{8}\right)$ is the largest fraction $[7,4,5]$. This BVOC is essentially uncontrollable compared to anthropogenic VOC emissions. Isoprene and other BVOCs are linked to the production of surface $\mathrm{O}_{3}$ [8; Hewitt et al., 2010) which leads to poor air quality and crop damage. Oil palm trees can emit significant amounts of isoprene 
[9]. In South East Asia (SEA), a large expansion in oil palm production is being driven by consumer demand for the oil for culinary use. Thus, understanding the controls of isoprene emissions from oil palm regions is important in the understanding of plant responses to future atmospheric conditions in Malaysia.

Previous study reported that isoprene is produced through a complex enzymatic reaction in the plant cell [10]. Dimethylallyl diphosphate (DMADP) in the chloroplast is the main enzyme involved in isoprene production. The emission rates of isoprene production from plants are influenced by meteorological factors such as temperature and light intensity, carbon dioxide $\left(\mathrm{CO}_{2}\right)$ concentrations, and oxygen $\left(\mathrm{O}_{2}\right)$ concentrations $[11,12]$. Oil palm plantations growing on peat soils are subject to debate concerning the magnitude of $\mathrm{CO}_{2}$ and methane $\left(\mathrm{CH}_{4}\right)$ losses from the peat $[13,14]$. The lack of continuous $\mathrm{CO}_{2}$ measurements in oil palm regions compared to tropical forest regions [15] has led to an unexplored relationship between $\mathrm{CO}_{2}$ and isoprene in palm oil regions.

According to [9], three major $\mathrm{NO}_{\mathrm{x}}$ sources are responsible for the increase in $\mathrm{NO}_{\mathrm{x}}$ over palm oil plantation areas, all linked to agro-industrial activity: vehicle exhaust, combustion at the palm oil processing plant, and substantial soil nitrogen fertilization in the plantations ( 0.5 tonnes of nitrogen per hectare per year) which lead to the increment of the surface $\mathrm{O}_{3}$ mixing ratios. The surface $\mathrm{O}_{3}$ formation potential is much higher, and so is an indirect impact of the conversion to oil palm region. Elevated surface $\mathrm{O}_{3}$ over many different regions has been observed over SEA and Malaysia in particular $[16,17,18]$. There were many previous studies conducted on isoprene emissions from various regions such as tropical regions [9], the United States [19], Asia [20, 8], and Europe [21]. However, observations on isoprene and its photochemistry over SEA are still sparse [9].

Continuous in situ isoprene measurements are further lacking compared to ex situ measurements. Ex situ sampling techniques include air flasks [9] and the sorbent tubes technique [22]. A study by [23] on continuous isoprene used the chemiluminescent technique known as Fast Isoprene Sensor (FIS) [23]. Over time it has become clear that a new robust continuous instrument is needed for real-time isoprene measurements. The combination of observation data and atmospheric models can be used for the forecasting and prediction of annual emissions of isoprene.

The gradual increment of oil palm plantation in the Pekan region is expected to generate larger amount of atmospheric isoprene. The reactive species is able to react rigorously with the local anthropogenic emission such $\mathrm{NO}_{\mathrm{x}}$ to produce ground $\mathrm{O}_{3}$ under the presence of sunlight. Therefore, the chemistry transport model emerges as an alternative to study the photochemical formation of $\mathrm{O}_{3}$ in response to the concentration change of these biogenic $\mathrm{O}_{3}$ precursors $[21 ; 8 ; 24 ; 20]$. The collective biogenic VOC emissions including isoprene are represented by emission models, such as the MEGAN model [25; see also https://bai.ess.uci.edu/megan/versions/megan3 for the updated model], based on extensive databases of species emissions each measured individually. Similar model applications have been ubiquitously studied, but very limited testing have been conducted for the oil palm plantation in the 
Peninsula Malaysia due to the lack of measurement data [26; 27]. Therefore, the availability of the in situ observation data in the current study has made possible the influence of isoprene emission from oil palm on the atmospheric composition over the region using models. Weather Research and Forecasting model coupled with Community Multiscale Air Quality Modelling (WRF-CMAQ) is applied to study the compositional change of atmospheric isoprene and $\mathrm{O}_{3}$ over years of rapid oil palm plantation expansion (2000 to 2016) as well as the transport of these atmospheric pollutants to the downwind region during the northeast monsoon season.

In this study, to the best of our knowledge, we conducted the first continuous in situ measurements of isoprene concentrations in a palm oil (Elaeis guineensis) plantation, certainly in Peninsular Malaysia. The main objective was to investigate the isoprene and surface $\mathrm{O}_{3}$ mixing ratios at $4 \mathrm{~m}$ above the canopy levels as well as their relationship with meteorological factors such as temperature, irradiance (light intensity), wind speed and direction, and relative humidity on isoprene. In addition, $\mathrm{CO}_{2}$ mixing ratios will also be discussed to investigate their implications on isoprene emissions. The implications are studied using the chemistry transport model WRF-CMAQ to assess the modelling system performance in the prediction of $\mathrm{O}_{3}$ levels and isoprene concentrations and emissions over the palm oil plantation. In Sect. 2, the experimental methodology is described. In Sect. 3 , the measurements are presented and analysed alongside the modelling results from WRF-CMAQ. Finally, conclusions are discussed in Sect. 4.

\section{Materials And Methods}

\section{Study site description}

In situ continuous measurements of isoprene, surface $\mathrm{O}_{3}$ and carbon dioxide $\left(\mathrm{CO}_{2}\right)$ were made at an oil palm plantation located on the east coast of Peninsular Malaysia ( $\left.3^{\circ} 26^{\prime} 17.8692^{\prime \prime} \mathrm{N}, 103^{\circ} 23^{\prime} 23.8056^{\prime \prime} \mathrm{E}\right)$ in the state of Pahang as shown in Figure 1. The oil palm plantation area is about 18,000 ha in extent. The sampling location is at the town of Pekan, approximately $30 \mathrm{~km}$ south of Kuantan, the capital city of Pahang. Heavy industries (oil and gas facilities, steel plants, and manufacturing industries) are common in the area. Recently, the introduction of Malaysia's first Special Economic Zone at Kuantan has boosted the local economy including through tourism. This increased industrial activity has made Kuantan a primary source for anthropogenic VOCs and other ozone precursors such as $\mathrm{NO}_{\mathrm{x}}$. These emissions have the potential to influence the levels of surface $\mathrm{O}_{3}$ and aerosols over the oil palm area.

\section{Fig. 1}

\section{Instrumentation and measurement procedures}

\section{Isoprene, $\mathrm{O}_{3}$ and $\mathrm{CO}_{2}$}

During the measurement period, isoprene, surface $\mathrm{O}_{3}$ and $\mathrm{CO}_{2}$ mixing ratios were measured at the eddy covariance (EC) tower (30 m height), owned by the Malaysian Palm Oil Board (MPOB). Each sample inlet 
was $10 \mathrm{~m}$ above the ground. Isoprene was measured during a 38-day period (6th December 2016 to 13 th January 2017), while surface $\mathrm{O}_{3}$ and $\mathrm{CO}_{2}$ were measured until the 31 st December 2016 due to the reinstallation of the $\mathrm{O}_{3}$ and $\mathrm{CO}_{2}$ analysers. The atmosphere immediately above the site was sampled using a $10 \mathrm{~m} \mathrm{1/4"} \mathrm{ID} \mathrm{Teflon} \mathrm{sample} \mathrm{line} \mathrm{(} 5 \mathrm{~m}$ above the oil palm canopy). Air was drawn from the inlet to the isoprene and $\mathrm{O}_{3}$ analysers. The $\mathrm{CO}_{2}$ measurements were made using a separate inlet system.

Surface $\mathrm{O}_{3}$ was measured using an EcoTech (Australia) model Serinus $10 \mathrm{O}_{3}$ analyser. The EcoTech was well-maintained and was calibrated immediately prior to the measurement period. The calibration was based on a 5-point standard technique with low to high concentrations from 0.01 to $100 \mathrm{ppb}$ (parts per billion by volume). The detection limit was estimated to be $0.05 \mathrm{ppb}$. The calibration procedure is described in [28].

Isoprene was measured using a new, portable Gas Chromatography with Photoionization detector (GCPID) named iDirac, which is a robust, autonomous instrument with good sensitivity to isoprene in ambient conditions as described details in [29]. A dual-bed adsorbent trap (1 mg Carboxen-1016 60/80 mesh followed by $1 \mathrm{mg}$ Carboxen-569 20/45 mesh) is used to pre-concentrate each sample. The trap is then heated and the gaseous constituents separated on a $10 \mathrm{~m}, 0.18 \mathrm{~mm}$ ID capillary column (Restek MXT 502.2) prior to measurement in the PID. Nitrogen is used as the carrier gas. The instrument is controlled by an Arduino and Raspberry Pi with Wi-Fi built in. As the instrument is designed to run unattended, the Raspberry Pi interface software runs chromatograms according to a pre-determined sequence of samples bracketed by calibration, blank and sample chromatograms. The sequence includes frequent calibrations using the same volume as the samples $(20 \mathrm{~mL})$ for correction of instrument sensitivity drift and precision determination. The unit can be used without a laptop in the field with two sample inlets and one calibration port for the calibration gas injection onto the PID. Solar power (12 V) was used to power up the iDirac throughout the campaign. iDirac has a power consumption of $\sim 10 \mathrm{~W}$. It typically has a precision of $<10 \%$, a detection limit of $\sim 20 \mathrm{ppt}$, and a sampling time of five minutes which depends on the sampling sequence chosen for a particular experiment [29].

$\mathrm{CO}_{2}$ mixing ratios were measured using an open-path infrared gas analyser (LI7500, LI-COR, USA). These measurements were made as part of a study to estimate $\mathrm{CO}_{2}$ fluxes over the oil palm plantation using EC [30]. A three-dimensional sonic anemometer (CSAT3, Campbell Scientific, USA) was also installed at the EC tower. The analyser and anemometer were factory-calibrated before use. The open-path analyser was calibrated in March 2016 to ensure accurate measurements. Nitrogen gas and drierite/soda lime were used to zero the $\mathrm{CO}_{2}$ and $\mathrm{H}_{2} \mathrm{O}$ sensors. Standard gas with $413 \mathrm{ppm} \mathrm{CO} \mathrm{CO}_{2}$ was used to analyse and monitor the $\mathrm{CO}_{2}$ readings, and a dew point generator was used to span the $\mathrm{H}_{2} \mathrm{O}$ range.

\section{Meteorological}

The meteorological data over the sampling site were collected using a "Biomet" system data logger (Xlite 9210, Sutron, USA). Air temperature and relative humidity sensors (HMP155, Vaisala, Netherlands) and quantum sensors (LI-190SL, LI-COR, USA) to measure photosynthetically active radiation (PAR) were 
installed at a height of $30.65 \mathrm{~m}$. The wind speed and direction were measured by a three-dimensional sonic anemometer (CSAT3, Campbell Scientific, USA). A tipping-bucket rain gauge (TR525, Texas Instruments Inc., USA) was employed to collect the 30-min accumulative precipitation.

\section{Secondary Data}

Finally, hourly averages of ozone, carbon monoxide (CO), nitrogen oxide (NO), nitrogen oxide $\left(\mathrm{NO}_{\mathrm{x}}\right)$ and nitrogen dioxide $\left(\mathrm{NO}_{2}\right)$ concentrations were measured at stations managed by Alam Sekitar Sdn Bhd (ASMA), a company which measures the air quality status on behalf of the Malaysian DOE in Kuantan. The two stations were located in Kuantan, S1 (N03 $\left.{ }^{\circ} 49.138, \mathrm{E} 103^{\circ} 17.817\right)$ and S2 (N03 ${ }^{\circ} 57.726$, $\left.\mathrm{E} 103^{\circ} 22.955\right)$. $\mathrm{S} 1$ is in a residential area, while $\mathrm{S} 2$ is in an industrial area which is a busy area with a high volume of motor vehicles moving in and out of the area. S2 area is dominated by petrochemical industries (mainly liquid natural gas). The $\mathrm{O}_{3}$ concentrations at the ASMA air monitoring stations were measured using a UV Absorption $\mathrm{O}_{3}$ Analyser (Teledyne Model 400A, USA). The concentrations of nitric oxide (NO) and $\mathrm{NO}_{2}$ were determined via chemiluminescence measurements, coupled with state-of-the-art microprocessor technology used for monitoring high and medium levels of nitrogen oxides (Teledyne Models 200A, USA). All instruments were calibrated by ASMA officers two times per month, near the start and end of the month (based on personal communication).

\section{WRF-CMAQ and MEGAN model set up}

The WRF version 3.9.1 coupled with CMAQ version 5.2.1 was utilized to study the meteorological and chemical parameters around the Pekan measurement site. Model simulations were performed at a horizontal resolution of $45 \mathrm{~km}$ (Southeast Asia), $15 \mathrm{~km}$ (West Malaysia), and $5 \mathrm{~km}$ (East Coast of West Malaysia) with a vertical profile resolution with 40 layers. The domain configuration is shown in Figure 2. NCEP GDAS/FNL research data, archived at a horizontal resolution of $0.5^{\circ} \times 0.5^{\circ}$ and temporal resolution of 6 hours, were used as the initial and lateral boundary conditions for the meteorological calculations. The longwave and shortwave radiative transfer computations were processed by the Rapid Radiative Transfer Model for General Circulation Models (RRTMG) (lacono et al., 2008). The cloud physics were represented by the Goddard scheme, the sub-grid convection processes by the Kain-Fristch parameterisation, the boundary layer by the Asymmetric Convective Model (ACM2), and the surface physics and land surface were derived using the Pleim-Xiu model. The land use dataset used was incorporated from the International Geosphere Biosphere Programme (IGBP) - Modified MODIS 21 land use categories. The gas-phase chemistry and aerosol mechanisms adopted in the model were CB05e51 and AE6 with aqueous chemistry. Dry deposition and the photolysis of gases were parameterized based on [31].

\section{Fig. 2}

The anthropogenic emissions were re-gridded for the model domain from the MIX dataset available at $0.25^{\circ} \times 0.25^{\circ}$ for the year 2010 [32]. This was not a major season for biomass burning, hence the model 
does not include the data for the relevant emissions. Biogenic emissions of trace species were calculated online using the Model of Emission of Gases and Aerosols from Nature (MEGAN) model version 2.1 [25], with several important updates: the incorporation of changes in land use (Ramankutty and Foley, 1999), the explicit consideration of oil palm emissions following the algorithm of [33], and the incorporation of corrections in ECMWF solar radiation fields based on surface solar radiation data [34; 35].

The input data of MEGAN was updated to the 8-day LAI index [36] and present-day plant functional types (PFT) [37]. In this paper, we have updated the emission factors for isoprene at the regions covered with oil palm with the measured results. Therefore, we have simulated two model cases with updated emission factors according to the distribution of oil palm over the Pekan region in the years (a) 2000 and (b) 2016 as shown in Figure 3. The increase of oil palm occurred across the Pekan region over these 10 years.

According to our results (discussed in Section 3.7), the emission factor for isoprene is updated to $6000 \mathrm{ug}$ $\mathrm{m}^{-2} \mathrm{~h}^{-1}$ as the MEGAN input for oil palm regions. After the emission-response calculation that accounts for the light and temperature responses, the MEGAN output increased the isoprene over central Pekan comparing the years 2016 and 2000 as shown in Figure 3(c). The model simulates December 2016 and January 2017, in line with the measurement campaign. It runs two separate cases with oil palm coverage of the years 2000 and 2016. The conversion of high isoprene-emitting agricultural land to oil palm in the north is the major cause of isoprene reduction here, while the reduction in the south is related to the introduction of oil palm due to forest clearing.

\section{Fig. 3}

\section{Result And Discussion}

Meteorological conditions and backward trajectories

The measurement period, December 2016 and January 2017, was during the North East Monsoon (NEM) when the prevailing wind flow is northeasterly and strong. Hourly average meteorological data consisting of temperature, relative humidity, wind (speed and direction) and irradiance were used to evaluate the weather conditions in this period. A summary of the meteorological conditions is given in Figure 4 . The minima for temperature and relative humidity $(\mathrm{RH})$ were $23.3^{\circ} \mathrm{C}$ and $43 \%$ with average values of $27.5^{\circ} \mathrm{C}$ and $82 \%$, respectively. The maximum temperature of $32.2^{\circ} \mathrm{C}$ occurred on the 13 th December 2014 . In January 2017, rain fell nearly continuously from the 11th to 13th January 2017 and this led to lower temperatures. The minimum temperatures recorded were during these days and were in the range 25.2 to $25.5^{\circ} \mathrm{C}$. The maximum temperature recorded in January 2017 was $29.2^{\circ} \mathrm{C}$ on the 10 th January.

The daily wind speed varied between $0.3 \mathrm{~ms}^{-1}$ and $8.8 \mathrm{~ms}^{-1}$ with a median value of $2.7 \mathrm{~ms}^{-1}$ during December 2016, while in January 2017 the respective values were $0.4 \mathrm{~ms}^{-1}$ and $9.3 \mathrm{~ms}^{-1}$ with a median value of $3.4 \mathrm{~ms}^{-1}$. The wind roses for these months are shown in Figure 4 . The wind directions were mainly blowing from the regions around Kuantan and Pekan. The highest daily maximum value of Photo 
Active Radiation (PAR) was $801 \mathrm{mMol} \mathrm{m}^{-2} \mathrm{~s}^{-1}$ on the $13^{\text {th }}$ December 2016 when the highest temperature was also recorded. The minimum daily PAR, $300 \mathrm{~W}$, was recorded during the rain event on the $11^{\text {th }}$ to $12^{\text {th }}$ January 2017.

\section{Fig. 4}

The travel pathways of the 3-day $(100 \mathrm{~m})$ backward trajectories (BTs) at Pekan palm oil plantation were plotted (Figure 5). As an input of the trajectory model, the data set was downloaded from the National Oceanic and Atmospheric Administration (NOAA) website (link: ftp://arlftp.arlhq.noaa.gov/pub/archives/reanalysis). The date of the BTs was the 12th December 2016. This day was selected as it was the day on which the highest mixing ratios were observed for isoprene. At the measurement site, the BTs showed transport from the northeast (NE) of Peninsular Malaysia. The mixing height was about $100 \mathrm{~m}$ on the 12th December 2016. The results of the trajectories can be interpreted with the elevation of surface $\mathrm{O}_{3}$ as well as the change to the height of the boundary layer. During the in situ measurements at the site, the mixing ratios of surface $\mathrm{O}_{3}$ were higher at the Pekan palm oil site. The nearby city Kuantan experienced high concentrations of $\mathrm{O}_{3}$ precursors such as $\mathrm{NO}_{\mathrm{x}}$ and $\mathrm{CO}$ (this will be discussed in the next Section) on this day. The noted shift of air mass in this region may in part influence the anthropogenic impact on the formation of surface $\mathrm{O}_{3}$ that might move with air masses around the palm site. We can conclude that the isoprene may react with the $\mathrm{NO}_{\mathrm{x}}$ and VOCs emitted from Kuantan.

Fig. 5

\section{Mixing ratios of isoprene, $\mathrm{O}_{3}$ and $\mathrm{CO}$}

The isoprene mixing ratios measured during December 2016 and January 2017 are shown in Figure 6. On some days (e.g. after $23^{\text {rd }}$ December), instrumental problems resulted in no measurements being made. A strong diurnal cycle is seen with the highest values between 1200 and 1400 local time. The maximum daytime peak values observed were $\sim 25 \mathrm{ppb}$ and occurred on the 12th and 19th December 2016 and on the 7th January 2017. The lowest daytime mixing ratios (peak $\sim 0.5 \mathrm{ppb}$ ) occurred on the 11th-13th January 2017. Minimum values of $<5 \mathrm{ppb}$ were found at night.

\section{Fig. 6}

This observation of high mixing ratios of isoprene during the day and low mixing ratios at night is consistent with many previous studies [38; 39; 40: 41]. The morning increase results principally from the strong influence of PAR and temperature on the emissions from the leaves into a stable planetary boundary layer $(\mathrm{PBL})$. The rate of the afternoon decrease is additionally affected by the loss to reaction with the hydroxyl radical (timescale $\sim 1$ hour), the main chemical loss process for isoprene, and transport into the lower troposphere. The rates of all these processes vary significantly from day to day. 
A similar diurnal cycle was found in the measured ozone mixing ratios, with a maximum in the day and a minimum at night (Figure 6). Typical daytime peaks are $\sim 40-50 \mathrm{ppb}$, with the highest hourly value of 57 ppb recorded on the 12th December 2016. These values are under the Malaysian Air Quality Standard for 1 hour and 8 hours which are 180 and 100 ppb, respectively. Surface $O_{3}$ values are determined by three main processes: (i) mixing in of ozone-rich tropospheric air into the PBL which is responsible for the morning increase in surface ozone; (ii) photochemical reactions involving ozone whose production will be enhanced by the presence of isoprene in $\mathrm{NO}_{x}$-rich air [9]; and (iii) deposition of ozone onto the oil palm plantation.

A strong diurnal cycle of $\mathrm{CO}_{2}$ was measured throughout December 2016 (Figure 6). Maximum mixing ratios were observed during the night and minimum values during the daytime with typical values of $\sim 810 \mathrm{ppm}$ and $\sim 450 \mathrm{ppm}$, respectively. Plant photosynthesis and respiration are the main reasons for these variations. Plants produce $\mathrm{CO}_{2}$ all the time through respiration, but during the day (when the light intensity is high) plants use $\mathrm{CO}_{2}$ for photosynthesis, and fix $\mathrm{CO}_{2}$ into other molecules, resulting in more $\mathrm{O}_{2}$ than $\mathrm{CO}_{2}$. At night, the $\mathrm{CO}_{2}$ increases because the plants are giving off $\mathrm{CO}_{2}$ in respiration and not photosynthesising. It can take until late morning before $\mathrm{CO}_{2}$ removal by photosynthesis is observable during the day.

\section{Physical factors effects on isoprene, surface $\mathrm{O}_{3}$ and $\mathrm{CO}_{2}$.}

\section{Effect on isoprene}

It has been observed that temperature and light intensity influence the isoprene emissions from plants $[42 ; 43 ; 44 ; 45]$. The light-dependent regulation of isoprene emissions is due to the production of isoprene in the plant photosynthesis process, therefore the photosynthetic active radiation during the day leads to higher daytime isoprene [46]. In this study, the irradiance term is similar to light intensity, thus irradiance in Watt per meter square $\left(\mathrm{Wm}^{-2}\right)$ will be used throughout. Figure 6 shows that increases in temperature and irradiance led to increases in isoprene mixing ratios. Strong correlations between temperature and irradiance with isoprene were observed with $r^{2}=0.91, p<0.01$ and $r^{2}=0.82, p<0.01$, respectively. The trends in isoprene, temperature and irradiance showed that the maximum peaks were observed during the middle of the day, from 1100 to 1530 . This was also observed by [41] for isoprene mixing ratios over Calabozo, Venezuela (Savanna site). They measured maximum mixing ratios of about $3.1 \mathrm{ppb}$ between 1200 and 1500 local time.

The isoprene synthesis and light dependence relationship can be explained by the synthesis of isoprene in the stomata. First observation of the light dependence of isoprene emissions was by [42], indicated by the rapid appearance of the $13 \mathrm{C}$ label from $13 \mathrm{C}$-labelled $\mathrm{CO}_{2}$ in the isoprene signal [43; 47]. An observation by [47] showed isolated chloroplasts are capable of isoprene emission which provided conclusive evidence of the functional interdependence between photosynthesis and isoprene emission.

\section{Effect on surface $\mathrm{O}_{3}$}

Page 10/32 
Previous studies have shown that surface $\mathrm{O}_{3}$ mixing ratios in ambient air are controlled by temperature $[17 ; 18 ; 16]$. Increases in temperature will increase the surface $\mathrm{O}_{3}$ mixing ratio in the presence of high levels of $\mathrm{NO}_{\mathrm{x}}$. Our observed variations in the daily maximum temperature and the daily maximum $\mathrm{O}_{3}$ mixing ratios are depicted in Figure 6. Overall, the average daily maximum temperatures and surface $\mathrm{O}_{3}$ measurements for Pekan palm station show increments, especially during the hours 1100 to 1630 , then gradual decreases after 1630 . This profile of surface $\mathrm{O}_{3}$ was consistent throughout December 2016 . The highest temperature recorded was $33^{\circ} \mathrm{C}$ on the 13 th December 2016 when the highest surface $\mathrm{O}_{3}$ also was observed. A similar effect of temperature on surface $\mathrm{O}_{3}$ was found over Kuala Terengganu, also on the east coast, $\sim 200 \mathrm{~km}$ from Pekan was seen in the study by [48]. Other than temperature, irradiance and wind speed were also found to play a significant role in influencing $\mathrm{O}_{3}$ mixing ratios [48].

The daily maximum temperature increased steadily from 0900 due to the increase of light intensity during the peak sun hours, where the irradiance that a particular location would receive if the sun were shining at its might i.e. as strongly as it can, as in no cloud cover. The increase in irradiance causes an increase of temperature, which in turn escalates the $\mathrm{O}_{3}$ mixing ratio maximum value. Similar to the temperature effect, the daily maximum $\mathrm{O}_{3}$ mixing ratio tended to follow the intensity of irradiance, causing higher levels during daytime and lower levels at night. The correlation between daily maximum temperature and daily maximum solar radiation was $r^{2}=0.91(p<0.01)$. This shows that these two parameters are strongly correlated with surface $\mathrm{O}_{3}$ production.

\section{Effect on surface $\mathrm{CO}_{2}$}

Light and temperature are two of the most influential parameters on photosynthesis activity. $\mathrm{CO}_{2}$ emissions are linked to the photosynthesis activity of plants. Plants consume more $\mathrm{CO}_{2}$ during the daytime during photosynthesis and release more during respiration at night. In this study, in contrast to the meteorological effects on isoprene and surface $\mathrm{O}_{3}$, temperature and solar radiation showed negative correlations with the $\mathrm{CO}_{2}$ mixing ratios as shown in Figure 6 . The daily $\mathrm{CO}_{2}$ maxima were in the range 580 to 780 ppm during the day while the minims were in the range 440 to $468 \mathrm{ppm}$ during the night. This profile of surface $\mathrm{CO}_{2}$ was consistent throughout December 2016.

These results imply that photosynthesis activity controls the mixing ratios of $\mathrm{CO}_{2}$. During the day (when light and temperature are high), $\mathrm{CO}_{2}$ is consumed to produce $\mathrm{O}_{2}$. High light intensity will lead to high temperatures usually during the daytime and results in stomata closing, which is also associated with high vapour pressure deficit (VPD). This means the effects of temperature and light intensity are reduced at low $\mathrm{CO}_{2}$ mixing ratios. According to [49], blue light (BL) has signal functions regulating many processes in chloroplast and stomatal opening in the leaf that may, in turn, affect isoprene emission. The $\mathrm{BL}$ also will be adsorbed by the stomata and influence $\mathrm{CO}_{2}$ diffusion in the leaf. Thus, $\mathrm{CO}_{2}$ and isoprene are believed to be influenced by the temperature and light intensity (especially the $\mathrm{BL}$ ) over the observation site. 


\section{The relationships between isoprene-surface $\mathrm{O}_{3}$ and isoprene- $\mathrm{CO}_{2}$.}

\section{Isoprene-surface $\mathrm{O}_{3}$}

As mentioned, the photochemistry of isoprene can dominate the photochemical production of $\mathrm{O}_{3}[50 ; 51$; 52; 53:54]. Both the production of isoprene and surface $\mathrm{O}_{3}$ were observed during the middle of the day throughout the measurement period. It is clearly shown that isoprene production influenced the surface $\mathrm{O}_{3}$ formation during this time (1100 to 1400 ) (see Figure 6 ). Secondary products of the isoprene and $\mathrm{OH}$ reaction interact with $\mathrm{NO}_{x}$ from anthropogenic sources to form surface $\mathrm{O}_{3}$. However, we were expecting the $\mathrm{NO}_{\mathrm{x}}$ mixing ratios over the palm oil region to be much lower compared to those over the urban area Kuantan (this will be discussed in the next Section).

The movement of vehicles (oil palm collection) is also an expected source of $\mathrm{NO}_{\mathrm{x}}$. According to [55], $\mathrm{O}_{3}$ production resulted from the oxidation of isoprene $\left(\mathrm{C}_{5} \mathrm{H}_{8}+\mathrm{OH} \rightarrow \rightarrow \mathrm{RO} 2+\mathrm{NO} \rightarrow \rightarrow \mathrm{O}_{3}\right)$. Higher levels of peroxyl radicals (RO2) during isoprene oxidation will enhance $\mathrm{O}_{3}$ production [55]. Therefore, if $\mathrm{NO}_{x}$ levels were high over the observed area, the production of ozone due to the oxidation of isoprene is expected to be higher than in areas with low $\mathrm{NO}_{x}$ emissions. [55] also suggested from their model calculation that the oxidation of isoprene also contributed to the enhancement of levels of carbonyls (such as formaldehyde and acetaldehyde). The formation of formaldehyde and acetaldehyde from isoprene oxidation will lead to the enhancement of $\mathrm{HO}_{2}$ radicals. The combination of increased carbonyls and $\mathrm{RO} 2$ in the atmosphere suggested the high observations of $\mathrm{O}_{3}$, especially during the middle of the day.

During the evening and night, isoprene removal is much faster (isoprene has a lifetime of $\sim 3$ hours) compared to the surface $\mathrm{O}_{3}$ removal process. These chemical removals can be explained by the lifetime of both gases, where surface $\mathrm{O}_{3}$ has longer than isoprene (a lifetime 3 hours) in the atmosphere (depending on the $\mathrm{NO}_{\mathrm{x}}$ emissions). In this study, strong daytime correlations between isoprene and surface $\mathrm{O}_{3}$ were observed with $\mathrm{r}^{2}=0.81(p<0.01)$, while weak correlations were observed during the evening and night with $r^{2}=0.43(p>0.01)$. The correlations between both gases were believed to be influenced by atmospheric lifetime and meteorological factors.

\subsubsection{Isoprene- $\mathrm{CO}_{2}$}

Isoprene and $\mathrm{CO}_{2}$ mixing ratios measured above the canopy are shown in Figure 6 . The diurnal cycle for both measured gases shows night and daytime variability for $\mathrm{CO}_{2}$ and isoprene. The maximum $\mathrm{CO}_{2}$ levels during the night are believed to be linked to plant respiration, while during daytime $\mathrm{CO}_{2}$ is used in the photosynthesis process. Average daily mixing ratios for isoprene and $\mathrm{CO}_{2}$ were 8.9 and $527.3 \mathrm{ppm}$ and 0.2 and $724.1 \mathrm{ppm}$ during the daytime and night, respectively. We believe that in a peat soil ecosystem there will be higher releases of $\mathrm{CO}_{2}$, mainly from the peat, but during the daytime, $\mathrm{CO}_{2}$ is taken up by the oil palm leading to decreasing $\mathrm{CO}_{2}$ mixing ratios. 
There is another unknown factor which drives the isoprene emission $\mathrm{CO}_{2}$ response. According to previous studies, high $\mathrm{CO}_{2}$ concentrations inhibit isoprene release into the atmosphere [45]. This has been hypothesized to reflect the inhibition of the activity of isoprene synthase (IspS) or another enzyme of the methylerythritol 4-phosphate (MEP) pathway [56]. This also supported by the evidence from a natural $\mathrm{CO}_{2}$ spring which showed that decreasing of isoprene emissions with increasing $\mathrm{CO}_{2}$ concentration could be linked to a reduction in IspS activity [57].

A study by [58] showed that across $\mathrm{CO}_{2}$ concentrations from 240 to 520 ppmv isoprene emissions from Eucalyptus globulus were enhanced at the lowest $\mathrm{CO}_{2}$ concentration. The study showed that the influence [58;59]. Process-based leaf-level isoprene production models were demonstrated by [59] and [58], also supporting the observation of Wilkinson et al. (2009) that enhanced $\mathrm{CO}_{2}$ levels will depress isoprene production. [60] showed that Triose Phosphate Utilization (TPU) limitation plays a key role in the suppression of isoprene emission from plants under high $\mathrm{CO}_{2}$ concentrations. Under conditions of high $\mathrm{CO}_{2}$ where TPU limits photosynthesis, both ATP and NADPH production are reduced, which under the energy hypothesis would reduce DMADP production [60]. Thus, during the night the reduction of DMADP in the Elaeis guineensis cell reduced the production of isoprene.

\subsection{Background information of local influenced from nearby city.}

Since we did not measure in situ $\mathrm{NO}_{x}$ at the oil palm site, we used secondary 2017 data for surface $\mathrm{O}_{3}$, $\mathrm{NO}, \mathrm{NO}_{2}, \mathrm{NO}_{\mathrm{x}}$ and $\mathrm{CO}$ from the continues air quality monitoring station (CAQMS) from the Department of Environment (DOE) sites in residential (S1) and industrial (S2) areas in Kuantan (Figure 1). These provide some information on the regional background composition. Two sites are available, one in an industrial area ( $\mathrm{N} 03^{\circ} 57.726$ and $\left.\mathrm{E} 103^{\circ} 22.955\right)$, the other in a residential zone ( $\mathrm{N} 03^{\circ} 49.138$ and $\left.\mathrm{E} 103^{\circ} 17.817\right)$. No other data over the region nearby Pekan are available and so we assume that they are representative of Kuantan as a whole and indicative of the atmospheric composition at Pekan when the wind is from Kuantan (see Figure 5). Table 1 shows a summary of monthly average mixing ratios for $\mathrm{O}_{3}, \mathrm{CO} \mathrm{NO}_{\mathrm{x}}, \mathrm{NO}_{2}$ and NO over the Kuantan city region during December 2017.

\section{Table 1}

Overall, the observations at the two sites are remarkably similar. The maximum average concentrations of surface $\mathrm{O}_{3}$ for the residential and industrial sites are $10 \mathrm{ppb}$ and $13 \mathrm{ppb}$, respectively, while those for $\mathrm{NO}_{x}$ are 10 and $15 \mathrm{ppb}$ (Figure 7). The mixing ratios of $\mathrm{O}_{3}$ and its precursors show typical diurnal variation patterns as found in previous studies in locations on the east coast of Malaysia including Kuantan [16-18].

\section{Fig. 7}

\section{Verification of WRF-CMAQ model result with observations}




\section{Isoprene}

Hourly distributions of simulated and observed isoprene mixing ratios over the Pekan palm oil plantation during December 2016 are shown in Figure 8. The model captured the diurnal variations and variabilities of the isoprene mixing ratio well throughout the study period. However, the maximum level of modeled isoprene occurred around $1200 \mathrm{LT}$, two hours earlier than the observed isoprene that was measured at $1400 \mathrm{LT}$. The average modeled isoprene was $2.49 \mathrm{ppb}$, slightly lower than the average measured isoprene of $2.63 \mathrm{ppb}$. The correlation coefficient between the simulated and observed isoprene mixing ratios was found to be 0.32 with an associated mean bias of $-0.14 \mathrm{ppb}$ over the location during December 2016 . High concentrations of isoprene were observed on the $12^{\text {th }}, 20^{\text {th }}$ and $23^{\text {rd }}$ December 2016 at noon and the model is able to capture these peaks. Meteorological parameters such as temperature, $\mathrm{RH}$, precipitation, $\mathrm{PBL}$, wind speed and wind direction have immense control over the BVOC production, distribution and dispersion processes. Observed monthly temperatures and RHs were $27.1^{\circ} \mathrm{C}, 26.2^{\circ} \mathrm{C}$ and $68 \%, 81.2 \%$, while the model found values around $26^{\circ} \mathrm{C}, 25.8^{\circ} \mathrm{C}$ and $82 \%, 85 \%$ in December 2016 and January 2017 respectively. This indicates a large difference in observed and simulated meteorological conditions except for wind speed (<10\%). Such differences in temperature and $\mathrm{RH}$ can result in large variations in the production of isoprene over the region.

Figure 8d shows the first few days of December 2016, where in the model isoprene is rigorously produced, although this turns to fall in line with the observations towards the end. For most of the days, the model could not produce isoprene concentrations ( $0 \mathrm{ppb})$ but did produce precipitation over the study location. Precipitation can trigger wet scavenging and leads to decreases in isoprene concentrations. In January 2017, the model performed well on the first few days, then deviated from the observations. Simulated low temperature and high $\mathrm{RH}$ during the study period clearly satisfy the persistence of low isoprene mixing ratios. Like other meteorological parameters, PBL heights also have a critical role in the model to simulate BVOCs [32]. The simulated PBL height over the location is directly proportional to the simulated isoprene and inversely proportional to the observed isoprene concentrations.

On the one hand, direct involvement of PBL height can be found on the emission, dispersion and transport of isoprene in the model. The influence of meteorological parameters on surface $\mathrm{O}_{3}$ means their inclusion in the model is essential due to their effects on isoprene by formation, transport and dispersion of surface $\mathrm{O}_{3}$, especially temperature, $\mathrm{PBLH}$ and $\mathrm{RH}$. On the other hand, direct involvement of PBL height can be found on the emission, dispersion and transport of isoprene in the model. Previous study reported that model simulated BVOCs such as isoprene, propene, acetone found low correlation coefficients with observations and large biases [61]. In general, the model was able to capture diurnal variations of the isoprene mixing ratio over the study location, but highly underestimated (30-40 \%) most of the days. Such discrepancies in the model can be due to the uncertainties in the dynamics, physics, surface process and the land use/land cover.

\section{Ozone}


The correlation coefficient between the simulated and the observed surface $O_{3}$ is 0.38 with rmsd of 19.1 $\mathrm{ppb}$. The influence of meteorological parameters on surface $\mathrm{O}_{3}$ is essential as its effect on isoprene by formation, transport and dispersion of surface $\mathrm{O}_{3}$, especially temperature, PBL height and $\mathrm{RH}$. In contrary with isoprene simulated surface $\mathrm{O}_{3}$ is overestimated most of the days $(\sim 35 \%)$, which shows the model producing surface $\mathrm{O}_{3}$ irrespective of isoprene deficiency. According to [62] and [63] the enhanced surface ozone formation is mainly attributed to factors such as oxidation of BVOCs and $\mathrm{CO}$ and the emission of isoprene from natural source. The simulated $\mathrm{CO}$ and $\mathrm{NO}_{\mathrm{x}}$ are compared with simulated surface $\mathrm{O}_{3}$ and found a high correlation among each species irrespective of isoprene. This strengthens the influence of $\mathrm{CO}$ on surface ozone formation and has a greater effect than isoprene in the model, and led to its overestimation over the study location. The major factors that influence the formation of surface $\mathrm{O}_{3}$ in the model are model resolution, meteorological conditions, spatial distribution of $\mathrm{O}_{3}$ precursors and the non-linearity in the photo chemical $\mathrm{O}_{3}$ formation [62]. Nevertheless, [62] suggests that, the spatial resolution of the model on the formation of $\mathrm{O}_{3}$ and $\mathrm{O}_{3}$ precursors have a large impact than the effect of the resolution associated with emission inventories.

In general, the simulated isoprene and surface $\mathrm{O}_{3}$ represents well over the palm oil plantation by the model during the study period from December 2016 and January 2017. However, an underestimation (30$40 \%$ ) observed on isoprene and a overestimation ( $<35 \%$ ) observed on surface $\mathrm{O}_{3}$ by the model when compared to observation. The discrepancies in the simulation of isoprene and $\mathrm{O}_{3}$ can be improved by further experiment on different model resolutions, meteorological conditions, model physical and dynamical behaviors, emission inventories and the biogenic emission process related to the land use / land cover in the model.

\section{Fig. 8}

\section{Model estimation of impact of land use change on the level of isoprene and ozone}

The conversion of forest land to oil palm mainly occurs in the central Pekan as discussed in Figure 3 . The difference of monthly-averaged isoprene profile between land use of 2016 and 2000 in December 2016 is shown in Figure 9 (a-d). The update of isoprene emission factor on oil palm region has shown clear increment over the source region. The change mainly occurred during the day from $0900-1900$ LT while isoprene is emitted in respect of the photochemical reactions. Despite a short-lived reactive gas, emitted isoprene is able to transport to inland up to $100 \mathrm{~km}$ downwind. This is likely due to the prevailing northeast monsoon during the December month. With the same period of time, the change of $\mathrm{O}_{3}$ is more localized over the source region (Figure $9(\mathrm{e}-\mathrm{f})$ ). $\mathrm{O}_{3}$ has clearly increased over the region where oil palm plantation has expanded.

\section{Fig. 9}

On the other hand, during January 2017, the isoprene does not show apparent difference compared to December 2016 and therefore $\mathrm{O}_{3}$ is not affected. The emission of isoprene greatly depends on the 
weather condition. The high temperature stress triggered large emission of isoprene that is potentially a self-protection mechanism. Figure 10 has shown the temperature difference between the January 2017 and December 2016. It is illustrated that the temperature in January 2017 is lower during the day as compared to December 2016. This is mainly attributed to the boreal winter cold air mass that is carried over to the SEA region along with the northeast monsoon. The model results clearly show a seasonal emission of isoprene, particularly over the east coast of west Malaysia.

\section{Fig. 10}

\section{Implications of new oil palm plantations near cities in Malaysia}

The average monthly isoprene emissions were found to be 5200 to $7000 \mathrm{ug} \mathrm{m}^{-2} \mathrm{~h}^{-1}$ over the Pekan palm oil plantation during the in situ measurements taken in December 2016 from MEGAN-based inventory as shown in Figure 11. Our emission rates were slightly higher than those of [64] over eastern Peninsular Malaysia with a range of 600 to $2500 \mathrm{ug} \mathrm{m}^{-2} \mathrm{~h}^{-1}$ during December-January-February 2005. This suggests that the impact of oil palm expansion in Malaysia is to enhance the trends of isoprene over the east coast of Peninsular Malaysia. Our measurements were similar to those of [33] and [9] over palm oil areas of Borneo Malaysia with values of $\sim 10000 \mathrm{ug} \mathrm{m}^{-2} \mathrm{~h}^{-1}$. [24] used the MEGAN model to show the emissions of isoprene started from $>6250 \mathrm{ug} \mathrm{m}^{-2} \mathrm{~h}^{-1}$ (e.g., some locations in Australia, eastern U.S., and the Amazon).

However, Silva et al. (2016) that showed their model prediction with different types of palm oil scenarios as input gave emission rates of isoprene over Borneo and Peninsula Malaysia with absolute differences in excess of $14 \mu \mathrm{mol} \mathrm{m}^{-2} \mathrm{~h}^{-1}$. The WRF-Chem model used by [65] showed lower emission rates of isoprene with $172.9 \mathrm{\mu g} \mathrm{g}^{-1} \mathrm{~h}^{-1}$ over palm oil areas in Distrito Metropolitano de Quito, Ecuador.

We concluded that the uncertainties of land use database input in different models may give different values to the emission rates. To better understand isoprene emission rates, we need more chemical transport models for comparison purposes for future emission predictions. In addition, ecosystem databases can be used to compute reasonable estimates of annual global isoprene emissions but may not produce accurate regional distributions [77].

\section{Fig. 11}

\section{Conclusions}

Surface $\mathrm{O}_{3}$, isoprene and $\mathrm{CO}_{2}$ were successfully measured for 41 days over the Pekan oil palm plantation. It is clear from the measurements that regions such as oil palm plantations can influence surface $\mathrm{O}_{3}$ formation in the presence of $\mathrm{NOx}$ and isoprene. In this study, the mixing ratios of surface $\mathrm{O}_{3}$ were strongly influenced by the emissions of isoprene (with strong correlation $r^{2}=0.81(p<0.01)$ ). Isoprene is believed to be emitted by Elaeis Guineensis as shown by our measurements. Meteorological 
factors such as temperature and irradiance showed strong correlations with the mixing ratios of isoprene, with $r^{2}=0.91, p<0.01$ and $r^{2}=0.82, p<0.01$, respectively. Surface $O_{3}$ was high during the middle of the day with a maximum value of $\sim 57 \mathrm{ppb}$. Local and regional winds carrying $\mathrm{NO}_{\mathrm{x}}$ from nearby cities such as Kuantan were also found to influence the mixing ratios of surface $\mathrm{O}_{3}$ produced from isoprene over the Pekan oil palm plantation. Surface $\mathrm{O}_{3}$ decreased during the night due to dry deposition and titration by $\mathrm{NO}_{\mathrm{x}}$. Furthermore, isoprene mixing ratios were suppressed by the elevated $\mathrm{CO}_{2}$ emissions during the night, believed to be due to the reduction of DMADP in the leaf cells. During photosynthesis, $\mathrm{CO}_{2}$ is consumed in the stomata leading to high isoprene emissions in the day. During respiration, $\mathrm{CO}_{2}$ is produced, leading to lower isoprene emissions from the leaves during the night. Thus, our findings concluded that temperature, irradiance and $\mathrm{CO}_{2}$ were the main factors controlling the levels of isoprene over the observation site. The WRF-Chem and WRF-CMAQ models were able to capture diurnal variations in the isoprene mixing ratio over the study location, although it highly underestimated $(30-40 \%)$ the mixing ratio most days. Such discrepancies in the model can be due to the uncertainties in the dynamics, physics, surface processes and the land use/land cover. In addition, the MEGAN model predicted emission rates of isoprene over the oil palm plantation site of 5200 to $7000 \mu \mathrm{g} \mathrm{m}^{-2} \mathrm{~h}-1$ which agrees with the MEGAN predictions from previous studies over oil palm plantation areas. In the future, long-term in situ measurements of isoprene together with other BVOCs such as monoterpenes, AVOCs and $\mathrm{O}_{3}$ precursors over palm oil plantations will be important for a better understanding of the reaction mechanisms of $\mathrm{O}_{3}$ production. Long-term in situ measurements of isoprene and surface $\mathrm{O}_{3}$ are also needed for better comparisons between different types of chemical transport model. Finally, it can be concluded that surface $\mathrm{O}_{3}$ formation associated with isoprene and isoprenoids from significant emitters

such as Elaeis Guineensis may be controlled by reducing or managing local or transported anthropogenic $\mathrm{NO}_{\mathrm{x}}$ and $\mathrm{VOC}$ emissions.

\section{Abbreviations}

\section{BVOCs}

Biogenic Volatile Organic Compounds, $\mathrm{C}_{5} \mathrm{H}_{8}$ :Isoprene, $\mathrm{O}_{3}$ :Ozone, $\mathrm{CO}_{2}$ :Carbon dioxide, $\mathrm{CH}_{4}$ :Methane, CO:Carbon monoxide, $\mathrm{NO}_{x}$ :Nitrogen oxide, $\mathrm{NO}_{2}$ :Nitrogen dioxide, $\mathrm{NO}$ :Nitric oxide, ppb:Part per billion, ppm:Part per million, DMADP:Dimethylallyl diphosphate, MEGAN:Model of Emissions of Gases and Aerosol from Nature, WRF; The Weather Research and Forecasting, CMAQ:Community Multiscale Air Quality Modeling System:WRF-CMAQ:The Weather Research and Forecasting-Community Multiscale Air Quality Modeling System, VOCs:Volatile Organic Compounds, MPOB:Malaysian Palm Oil Board, ID:Inner diameter, GC-PID:Gas Chromatography with Photoionization detector, ASMA:Alam Sekitar Sdn Bhd, UV:Ultraviolet, GDAS:Global Data Assimilation System, NCEP:National Center for Environmental Prediction, FNL:Final, IGBP:International Geosphere Biosphere Programme, ECMWF:European Centre for Medium-Range Weather Forecasts, PFT:Plant functional types, NEM:North East Monsoon, RH:Relative humidity, PAR:Photo Active Radiation, NOAA:National Oceanic and Atmospheric Administration, $\mathrm{BT}$ :backward trajectories, PBL:Planetary boundary layer, $\mathrm{r}^{2}$ :Coefficient correlation, p:probability, 
VPD:vapour pressure deficit, $\mathrm{BL}$ :blue light, $\mathrm{HO}_{2}$ :ISpS:hydroperoxyl radical, isoprene synthase, MEP:methylerythritol 4-phosphate, TPU:Triose Phosphate Utilization, LT:Lower troposphere.

\section{Declarations}

\section{Ethics approval and consent to participate}

Not applicable

Consent for publication

Not applicable

\section{Availability of data and materials}

The backward trajectories used in this study was downloaded from ftp://arlftp.arlhq.noaa.gov/pub/archives/reanalysis.

\section{Competing interests}

The authors declare no competing interests.

\section{Funding}

Research grant registered as Sciencefund 06-01-02-SF1274 at Universiti Kebangsaan Malaysia (UKM) and GUP-2018-135 grant provided by UKM. The UK Natural Environment Research Council (NERC) sponsored the iDirac development in BALI (NE/ K016377/1).

\section{Authors' contributions}

MSM-N and NRP-H conceptualized the idea. MSM-N, MCG-O and C-B aided in the study design. MSM-S, and HHA-H performed the air sampling procedures. MCG-O, SH-B and R-M did the modelling analyses. MSM-N and NRP-H wrote the early versions of the manuscript. All authors contributed equally to the data analysis and interpretations. All authors co-wrote the final version of the paper.

\section{Acknowledgments}

We would like to thank Ministry of Science, Technology and Innovation (MOSTI) for the research grant registered as Sciencefund 06-01-02-SF1274 at Universiti Kebangsaan Malaysia (UKM) and GUP-2018-135 grant provided by UKM. Prof Dr. Neil Harris would like to thank The UK Natural Environment Research Council (NERC) sponsored the iDirac development in BALI (NE/ K016377/1). We also like to thank NERC for the Doctoral Training Partnership for Conor Bolas, Malaysia Meteorological Department (Met Malaysia) and ASPA palm oil management and MPOB for their scientific contributions. We would also 
like to thank MPOB for the EC tower sites and technical supports given during the research period. Finally, we also like to thank Dr Rose Norman from United Kingdom for her assistance in proofreading this article.

\section{Authors' information}

Not applicable

\section{References}

1. Sharkey TD, Singsaas EL. Why plants emit isoprene. Nature. 1995;374:769.

2. Sharkey TD, Yeh SS. Isoprene emission from plants. Annu Rev Plant Physiol Plant Mol Biol. 2001;52:407-36.

3. Karl T, Potosnak M, Guenther A, Clark D, Walker J, Herrick JD, Geron C. Exchange processes of volatile organic compounds above a tropical rain forest: Implications for modeling tropospheric chemistry above dense vegetation. J Geophys Res-Atmos 2004;109: doi:10.1029/2004JD004738.

4. Karl T, Guenther A, Yokelson RJ, Greenberg J, Potosnak M, Blake DR, Artaxo P. The tropical forest and fire emissions experiment: Emission, chemistry, and transport of biogenic volatile organic compounds in the lower atmosphere over Amazonia. J Geophys Res. 2007;112: doi:10.1029/2007JD008539.

5. Ekberg A, Arneth A, Hakola H, Hayward S, Holst T. Isoprene emission from wetland sedges. Biogeosciences. 2009;6(4):601-13.

6. Nadzir MSM, Cain M, Robinson AD, Bolas C, Harris NRP, Parnikoza I, Salimun E, Mustafa EM, Alhasa KM, Zainuddin MHM, Ghee OC, Morris K, Khan MF, Latif MT, Wallis BM, Cheah W, Zainudin SK, Yusop N, Ahmad MR, Hussin WMRW, Salleh SM, Hamid HHA, Lai GT, Uning R, Bakar MAA, Ariff NM, Tuah Z, Wahab MIA, Foong SY, Samah AA, Chenoli SN, Wan Johari WL, Zain CRCM, Rahman NA, Rosenstiel TN, Yusoff AH, Sabuti AA. Alias SA and Noor AYM. Isoprene hotspots at the Western Coast of Antarctic Peninsula during MASEC'16. Polar Sci. 2019. doi:10.1016/j.polar.2018.12.006.

7. Guenther A, Karl T, Harley P, Wiedinmyer C, Palmer PI, Geron C. Estimates of global terrestrial isoprene emissions using MEGAN (Model of Emissions of Gases and Aerosols from Nature). Atmos Chem Phys. 2006;6:3181-210.

8. Pang $X, M u Y$, Zhang Y, Lee $X$, Yuan J. Contribution of isoprene to formaldehyde and ozone formation based on its oxidation products measurement in Beijing. China Atmos Environ. 2009;43:2142-7.

9. Hewitt CN, et al. Nitrogen management is essential to prevent tropical oil palm plantations from causing ground-level ozone pollution. Proc. Natl Acad. Sci. USA. 2009. 106, 18447-18451.

10. Sharkey TD, Gray DW, Pell HK, Breneman SR, Topper L. Isoprene synthase genes form a monophyletic clade of acyclic terpene synthases in the TPS-B terpene synthase family. Evolution. 2013;67:1026-40. doi:10.1111/evo.12013. 
11. Cole M. Combinatory effect of changing $\mathrm{CO}_{2}$, temperature, and long-term growth temperature on isoprene emissions. Depaul Discoveries. 2016;5:15.

12. Staudt M, Morin X, Chuine I. Contrasting direct and indirect effects of warming and drought on isoprenoid emissions from Mediterranean oaks. Reg Environ Change. 2016;17:2121-33. doi:10.1007/s10113-016-1056-6.

13. Evers S, Yule CM, Padfield R, O'Reilly P, Varkkey H. Keep wetlands wet: the myth of sustainable development of tropical peatlands-implications for policies and management. Glob Change Biol. 2017;23:534-49. doi:10.1111/gcb.13422.

14. Wijedasa LS, Jauhiainen J, Könönen M, Lampela M, Vasander H, Leblanc MC, et al. Denial of longterm issues with agriculture on tropical peatlands will have devastating consequences. Glob Change Biol. 2017;23:977-82. doi:10.1111/gcb.13516.

15. Manning FC, Kho LK, Hill TC, Cornulier T, The YA. Carbon Emissions From Oil Palm Plantations on Peat Soil. Front For Glob Change. 2019;2:37. doi:10.3389/ffgc.2019.00037.

16. Latif MT, Huey LS, Juneng L. Variations of surface ozone concentration across the Klang Valley, Malaysia. Atmos Environ. 2012;61:434-45.

17. Banan N, Latif MT, Juneng L, Ahamad F. Characteristics of surface ozone concentrations at stations with different backgrounds in the Malaysian Peninsula. Aerosol Air Quality Research. 2013;13:1090106.

18. Ahamad F, Latif MT, Tang R, Juneng L, Dominick D, Juahir H. Variation of surface ozone exceedance around Klang Valley, Malaysia. Atmos Res. 2014;139:116-27.

19. Dunker AM, Koo B, Yarwood G. Sensitivity of atmospheric models to rate terms within complex chemical mechanisms. Atmos Environ. 2014;98:224-30.

20. Han KM, Park RS, Kim HK, Woo JH, Kim J, Song CH. Uncertainty in biogenic isoprene emissions and its impacts on tropospheric chemistry in East Asia. Sci Total Environ. 2013;463:754-71.

21. Dufour G, Wittrock F, Camredon M, Beekmann M, Richter A, Aumont B, Burrows JP. SCIAMACHY formaldehyde observations: constraint for isoprene emission estimates over Europe? Atmos Chem Phys. 2009;9:1647-64.

22. Geng F, Tie X, Guenther A, Li G, Cao J, Harley P. Effect of isoprene emissions from major forests on ozone formation in the city of Shanghai. China Atmos Chem Phys. 2011;11:10449-59:. doi:10.5194/acp-11-10449-2011.

23. Guenther AB, Monson RK, Fall R. Isoprene and monoterpene emission rate variability: Observations with eucalyptus and emission rate algorithm development. J Geophys Res. 1991;96:10799-808.

24. Guenther AB, Karl T, Harley P, Wiedinmyer C, Palmer PI, Geron C. Estimates of global terrestrial isoprene emissions using MEGAN (Model of Emissions of Gases and Aerosols from Nature). Atmos Chem Phys. 2006;6:3181-210.

25. Guenther AB, Jiang X, Heald CL, Sakulyanontvittaya T, Duhl T, Emmons LK, Wang X. The Model of Emissions of Gases and Aerosols from Nature version 2.1 (MEGAN2.1): an extended and updated 
framework for modeling biogenic emissions, Geosci. Model Dev Discuss. 2012;5:1503-60.

26. Ooi MCG, Chan A, Ashfold MJ, Oozer MY, Moris KI, Kong SSK. The role of land use on the local climate and air quality during calm inter-monsoon in a tropical city Geosci. Front. 2019;10(2):40515.

27. Langford AO, Tucker S, Senff C, Banta R, Brewer W, Alvarez R, Hardesty R, Lerner B, Williams E. Convective venting and surface ozone in Houston during TexAQS2006. J Geophys Res. 2010;115:D16305.

28. Nadzir MSM, Ashfold MJ, Khan MF, et al. Environ Sci Pollut Res. 2018;25:2194.

29. Bolas CG, Ferracci V, Robinson AD, Mead MI, Nadzir MSM, Pyle JA, Jones RL, Harris NRP. iDirac: a field-portable instrument for long-term autonomous measurements of isoprene and selected VOCs. Atmos Meas Tech. 2020;13:821-38.

30. Burba G, Anderson D. A brief practical guide to Eddy Covariance flux measurements: principles and workflow examples for scientific and industrial applications. USA: LI-COR Biosciences; 2010. version 1.0.1.

31. Wesely ML. Parameterization of surface resistance to gaseous dry deposition in regional scale, numerical models. Atmos Environ. 1989;23:1293-304.

32. Li M, Zhang Q, Kurokawa JI, Woo JH, He K, Lu Z, Ohara T, Song Y, Streets DG, Carmichael GR, Cheng Y, Hong C, Huo H, Jiang X, Kang S, Liu F, Su H, Zheng B. MIX: a mosaic Asian anthropogenic emission inventory under the international collaboration framework of the MICS-Asia and HTAP. Atmos Chem Phys. 2017a;17:935-63.

33. Misztal PK, Nemitz E, Langford B, Di Marco CF, Phillips GJ, Hewitt CN, MacKenzie AR, Owen SM, Fowler D, Heal MR, Cape JN. Direct ecosystem fluxes of volatile organic compounds from oil palms in South-East Asia. Atmos Chem Phys. 2011;11:8995-9017.

34. Wild M. Global dimming and brightening: A review. Journal of Geophysical Research-Atmospheres. 2009;114:D00D16.

35. Xia XA. Spatiotemporal changes in sunshine duration and cloud amount as well as their relationship in China during 1954-2005. Journal of Geophysical Research Atmospheres. 2010;115: doi:10.1029/2009JD012879.

36. Yuan H, Dai Y, Xiao Z, Ji D, Shangguan W. Reprocessing the MODIS Leaf Area Index products for land surface and climate modelling. Remote Sens Environ. 2011;115:1171-87.

37. Technical Description of version 4.0 of the Community Land Model (CLM), NCAR/TN-478 + STR.2010.

Oleson KW, Lawrence DM, Bonan GB, Flanner MG, Kluzek E, Lawrence PJ, Levis S, Swenson SC, Thorn-ton PE, Dai A, Decker M, Dickinson R, Feddema J, Heald CL, Hoffman F, Lamarque J-F, Mahowald N, Niu G-Y, Qian T, Randerson J, Running S, Sakaguchi K, Slater A, Stockli R, Wang A, Yang Z-L, Zeng X, Zeng X. Technical Description of version 4.0 of the Community Land Model (CLM), NCAR/TN-478 + STR.2010. 
38. Montzka SA, Trainer M, Goldan PD, Kuster WC, Fehsenfeld FC. Isoprene and its oxidation-products, methyl vinyl ketone and methacrolein, in the rural troposphere. J Geophys Res-Atmos. 1993;98:1101-11.

39. Goldan PD, Kuster WC, Fehesenfeld FC, Montzka SA. Hydrocarbon measurements in the southeastern United States: The Rural Oxidants in the Southern Environment (ROSE) program 1990. J Geophys Res-Atmos. 1995;103:31045-56.

40. Biesenthal TA, Wu Q, Shepson PB, Wiebe HA, Anlauf KG, Mackay GI. A study of relationship between isoprene, its oxidation products, and ozone, in the lower Fraser valley, BC. Atmos Environ. 1997;31:2049-58.

41. Holzinger R, Kleiss B, Donoso L, Sanhueza E. Aromatic hydrocarbons at urban, sub-urban, rural $\left(8^{\circ} 520^{\prime} \mathrm{N} ; 67^{\circ} 190^{\prime} \mathrm{W}\right)$ and remote sites in Venezuela, Atmos. Environ. 2001;35:29:4917-27.

42. Sanadze GA. Light-dependent excretion of molecular isoprene. Prog Photosynth Res. 1969;2:701-7.

43. Sanadze GA. Isoprene effect (light-dependent emission of isoprene by green parts of plants. In: Sharkey TD, Holland EA, Mooney HA, editors. Trace gas emissions by plants. San Diego (CA): Academic Press; 1991. p. 135152.

44. Monson R, Harley P, Litvak M, Wildermuth M, Guenther A, Zimmerman P, Fall R. Environmental and developmental controls over the seasonal pattern of isoprene emission from aspen leaves. Oecologia. 1994;99:260-70.

45. Loreto F, Sharkey TD. A gas-exchange study of photosynthesis and isoprene emission in Quercus rubra L. Planta. 1990;182:523-31.

46. Rasulov B, Hüve K, Välbe M, Laisk A, Niinemets Ü. Evidence that light, carbon dioxide and oxygen dependencies of leaf isoprene emission are driven by energy status in hybrid aspen. Plant Physiol. 2009;151:448-60.

47. Mgalobilishvili MP, Khetsuriani ND, Kalandadze AN, Sanadze GA. Localization of isoprene biosynthesis in poplar leaf chloroplasts. Fiziol Rast. 1978;25:1055-61.

48. Abdullah AM, Ismail M, Yuen FS, Abdullah S, Elhadi RE. The relationship between daily maximum temperature and daily maximum ground level ozone concentration. Polish Journal of Environmental Studies. 2017;26(2):517-23.

49. Pallozzi E, Fortunati A, Marino G, Loreto F, Agati G, Centritto M. BVOC emission from Populus $x$ canadensis saplings in response to acute UV-A radiation. Physiol Plantarum. 2013a;148:51-61.

50. Williams $\mathrm{J}$, et al. Regional ozone from biogenic hydrocarbons deduced from airborne measurements of PAN, PPN and MPAN, Geophys. Res Lett. 1997;24:1099-102.

51. Roberts JM, et al. Measurements of PAN, PPN, and MPAN made during the 1994 and 1995 Nashville intensives of the southern oxidant study: Implications for regional ozone production from biogenic hydrocarbons. J Geophys Res. 1998;103:22,473-22,490.

52. Starn TK, Shepson PB, Bertman SB, White JS, Splawn BG, Riemer DD, Zika RG, Olszyna K. Observations of isoprene chemistry and its role in ozone production at a semirural site during the 
1995 Southern Oxidants Study. J Geophys Res. 1998a;103:22,425-22,435.

53. Staudt M, Morin X, Chuine I. Contrasting direct and indirect effects of warming and drought on isoprenoid emissions from Mediterranean oaks. Reg Environ Change. 2016;17:2121-33. doi:10.1007/s10113-016-1056-6.

54. Roberts JM, Flocke F, Stroud CA, Hereid D, Williams EJ, Fehsenfeld FC, Brune WH, Martinez Harder M, Harder H., 2002. Groundbased measurements of PANs during the 1999 Southern Oxidant Study Nashville intensive, J. Geophys. Res., 107.

55. Geng F, Tie X, Guenther A, Li G, Cao J, Harley P. Effect of isoprene emissions from major forests on ozone formation in the city of Shanghai, China. Atmos Chem Phys. 2011;11:10449-59.

56. Potosnak MJ Effects of growth carbon dioxide concentration on isoprene emissions from plants. PhD thesis. 2002;Columbia University: New York.

57. Scholefield PA, Doick KJ, Herbert B, Hewitt CN, Schnitzler JP, Pinelli P, Loreto F. 2004. Impact of rising $\mathrm{CO}_{2}$ on VOC emissions: isoprene emission from Phragmites australis growing at elevated $\mathrm{CO}_{2}$ in a natural carbon dioxide spring. Plant Cell Environ. 2004;27:393-401.

58. Wilkinson MJ, Monson RK, Trahan N, Lee S, Brown E, Jackson RB, Polley HW, Fay PA, Fall R. Leaf isoprene emission rate as a function of atmospheric $\mathrm{CO} 2$ concentration. Global Change Biol. 2009;15:1189-200.

59. Arneth A, Niinemets Ü, Pressley S, et al. Process-based estimates of terrestrial ecosystem isoprene emissions: incorporating the effects of a direct C02-isoprene interaction. Atmos Chem Phys. 2007;7:31-53.

60. Lantz AT, Solomon C, Gog L, McClain AM, Weraduwage SM, Cruz JA, Sharkey TD. Isoprene Suppression by $\mathrm{CO}_{2}$ Is Not Due to Triose Phosphate Utilization (TPU) Limitation. Front For Glob Change. 2019;2:8.

61. Zhang Y, et al. Comparisons of WRF/Chem simulations in Mexico City with ground-based RAMA measurements during the 2006-MILAGRO. Atmos Chem Phys. 2009;9:11:3777-3798.

62. Tie X, Madronich S, Li G, Ying Z, Weinheimer A, Apel E, Campos T. Simulation of Mexico City plumes during the MIRAGE-Mex field campaign using the WRF-Chem model. Atmospheric Chemistry Physics. 2009;9:4621-38.

63. Geng F, Tie X, Guenther A, Li G, Cao J, Harley P. Effect of isoprene emissions from major forests on ozone formation in the city of Shanghai. China Atmos Chem Phys. 2011;11:10449-59.

64. Stavrakou T, Müller J-F, Bauwens M, De Smedt I, Van Roozendael M, Guenther A, Wild M, Xia X. Isoprene emissions over Asia 1979-2012: impact of climate and land-use changes. Atmos Chem Phys. 2014;14:4587-605.

65. Parra R. Contribution of oil palm isoprene emissions to tropospheric ozone levels in the Distrito Metropolitano de Quito (Ecuador). WIT Trans Ecol Environ. 2008;116:95-104.

\section{Tables}




\section{Table 1}

Summary of monthly average measured parameters at DOE's Kuantan sites in December 2017.

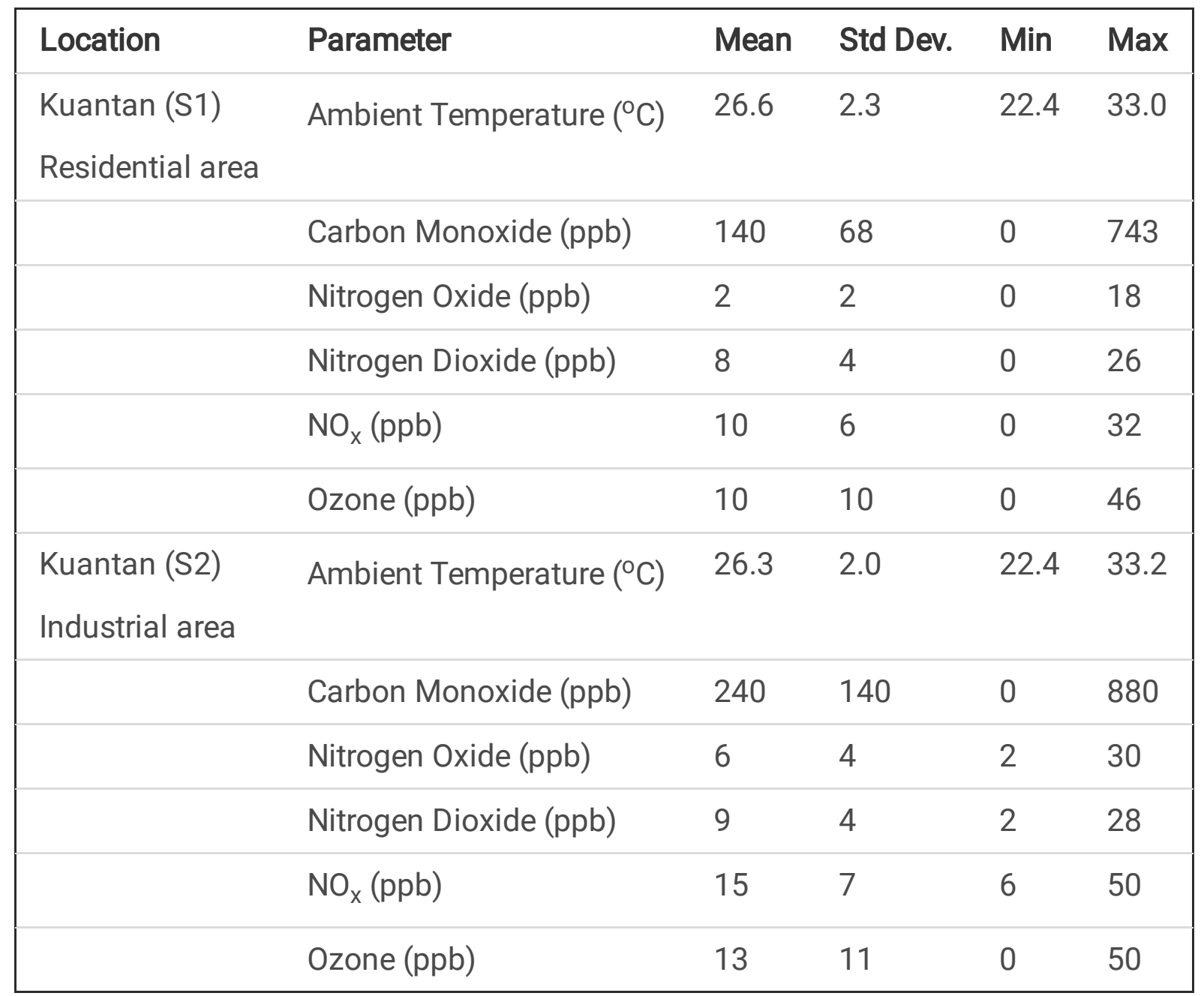

\section{Figures}




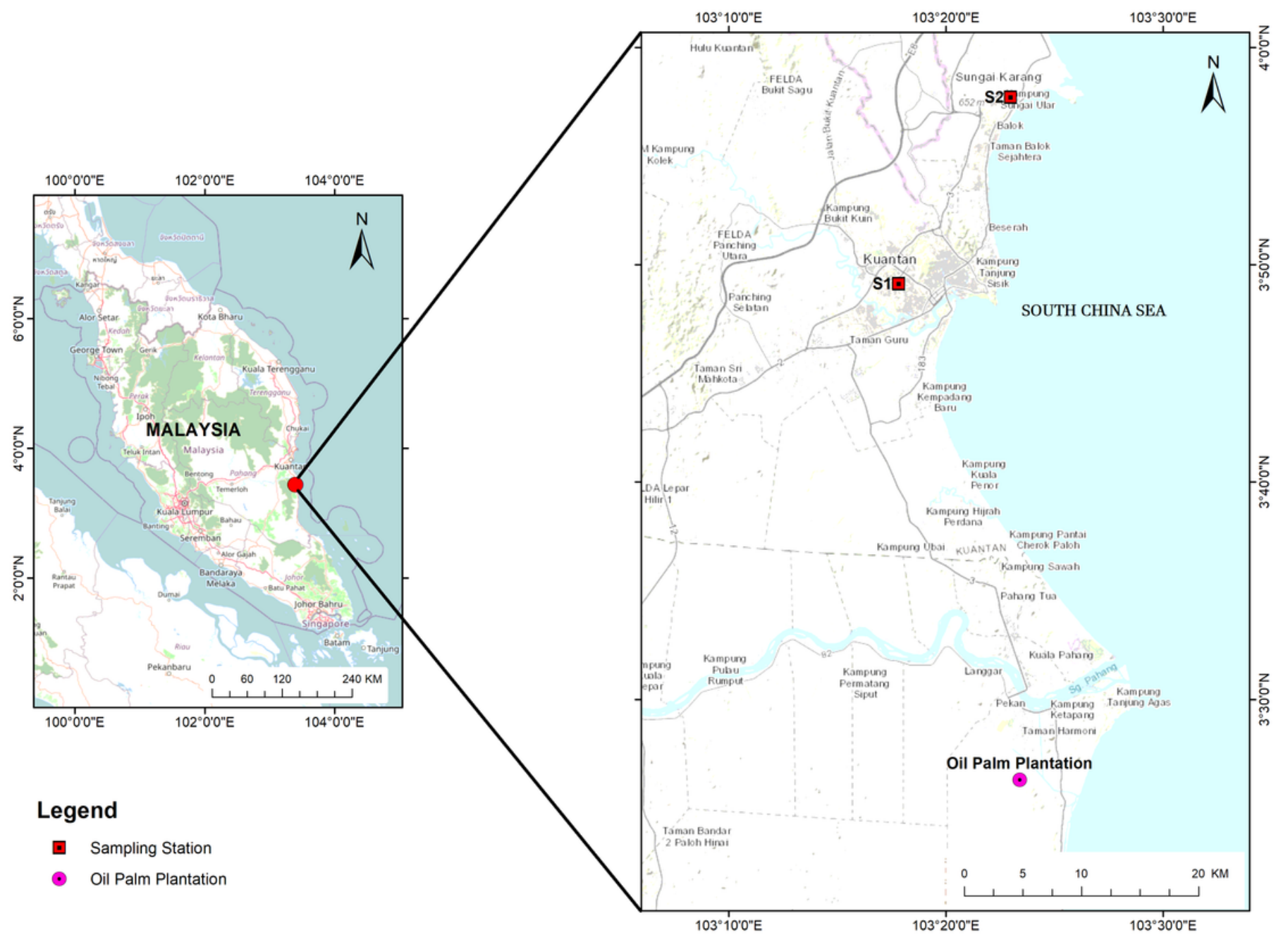

\section{Figure 1}

Location of the Pekan oil palm plantation (left) on the Malaysian Peninsula and (right in respect to the city of Kuantan. S1 and S2 are the two DOE air quality monitoring stations whose data are used in this study. Note: The designations employed and the presentation of the material on this map do not imply the expression of any opinion whatsoever on the part of Research Square concerning the legal status of any country, territory, city or area or of its authorities, or concerning the delimitation of its frontiers or boundaries. This map has been provided by the authors. 


\section{WPS Domain Configuration}

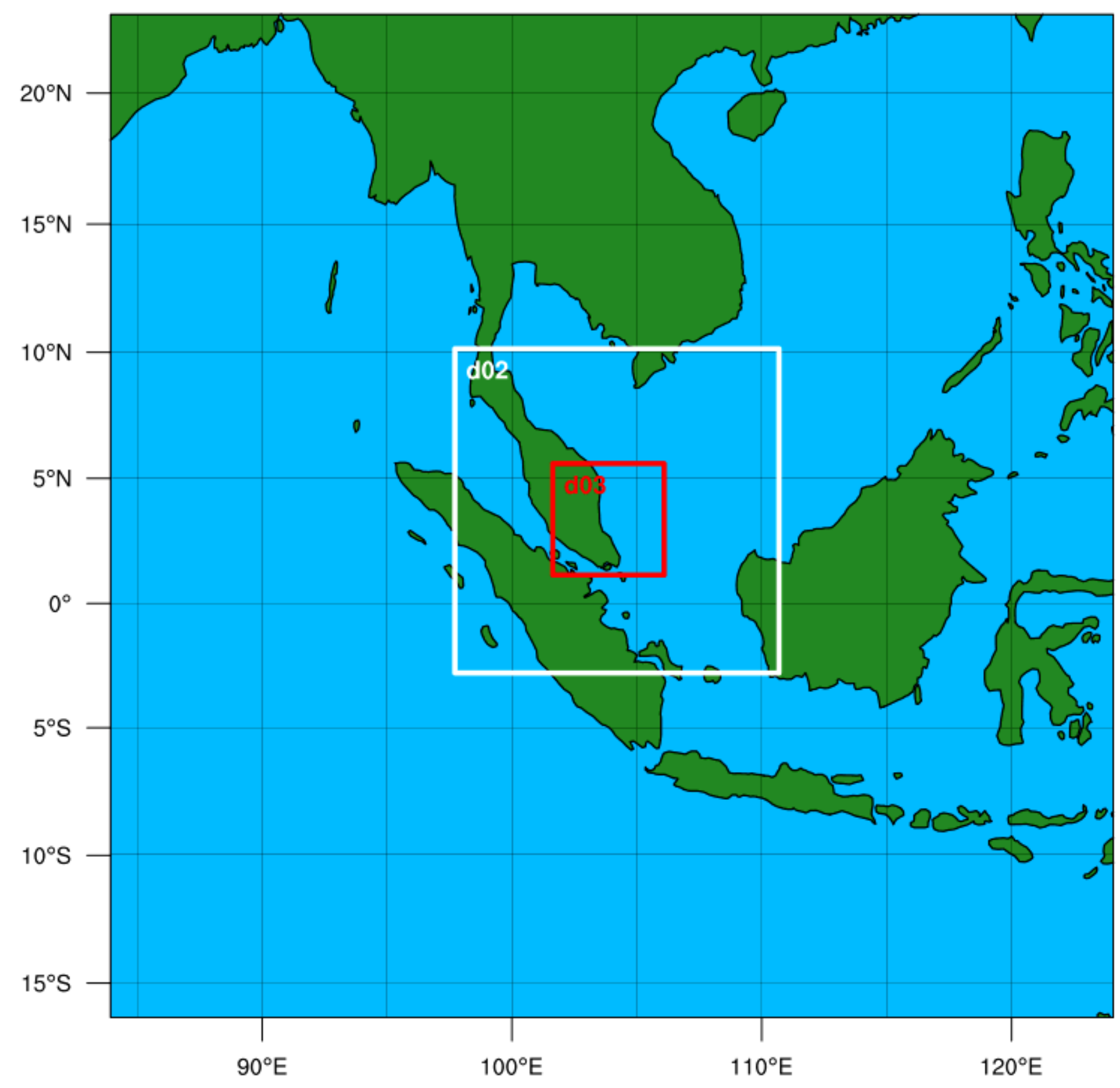

Figure 2

Domain configuration for WRF model. Note: The designations employed and the presentation of the material on this map do not imply the expression of any opinion whatsoever on the part of Research Square concerning the legal status of any country, territory, city or area or of its authorities, or concerning the delimitation of its frontiers or boundaries. This map has been provided by the authors. 

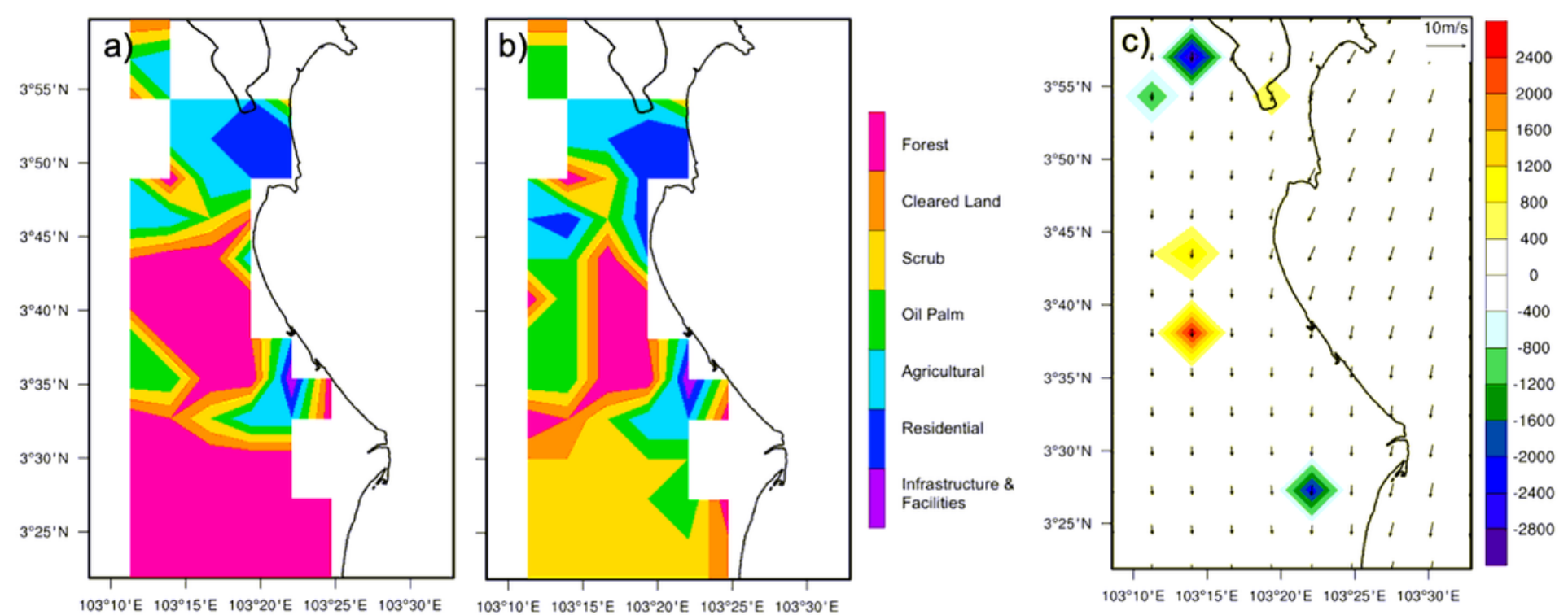

Figure 3

Updated land use input for the Pekan region for WRF \& MEGAN at a resolution of $5 \mathrm{~km}$ in (a) 2000, (b) 2016. (c) The difference in the monthly-averaged emission factor of isoprene at $1400 \mathrm{LT}$ between 2016 and 2000 ( $\mu \mathrm{g} \mathrm{m}-2 \mathrm{~h}-1)$.
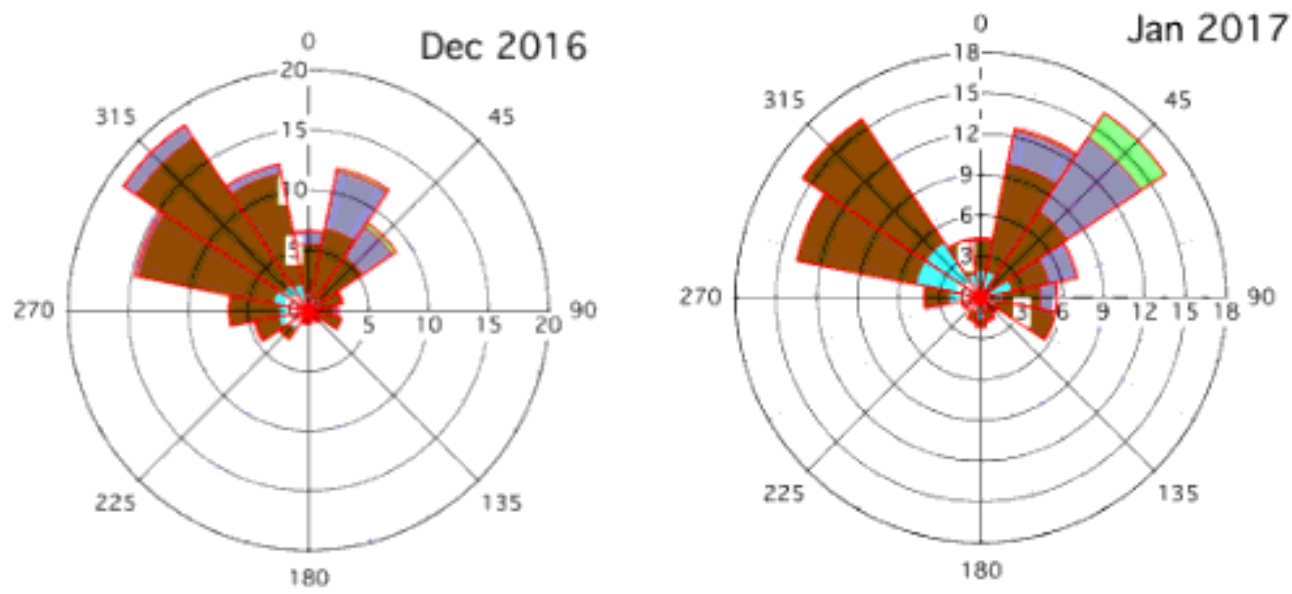

Wind Speed $(\mathrm{m} / \mathrm{s})$

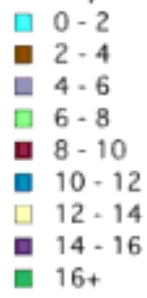

Figure 4

Wind roses and daily average wind speeds for December (8th to 22nd December 2016) and January (1st to 12th January 2017). 


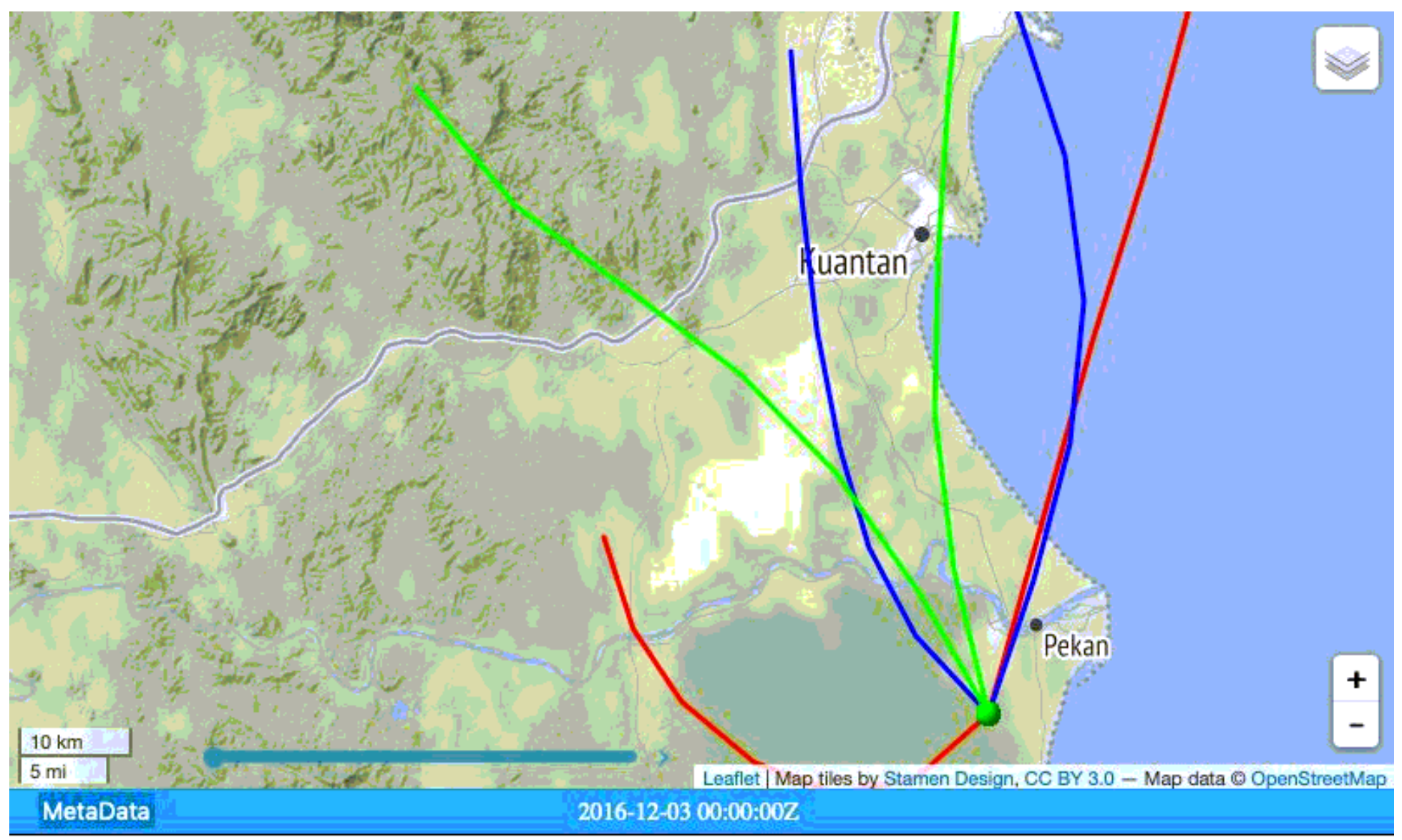

\section{Figure 5}

day $(100 \mathrm{~m})$ backward trajectories (BTs) at Pekan palm oil plantation during field measurement. Note: The designations employed and the presentation of the material on this map do not imply the expression of any opinion whatsoever on the part of Research Square concerning the legal status of any country, territory, city or area or of its authorities, or concerning the delimitation of its frontiers or boundaries. This map has been provided by the authors. 


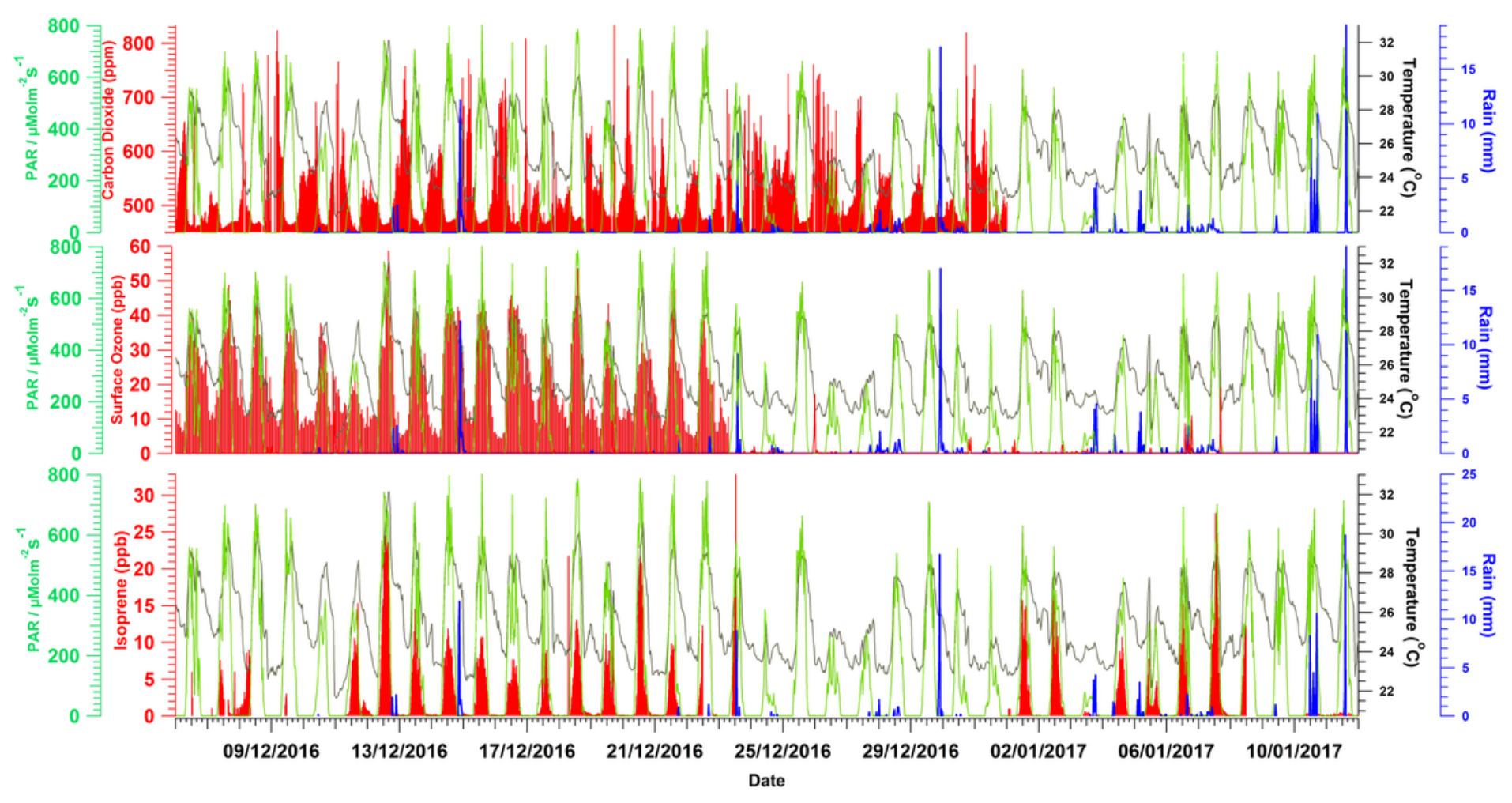

Figure 6

Daily mixing ratios of isoprene, ozone, carbon dioxide and meteorological parameters measured above the palm tree canopy during December 2016 and January 2017.

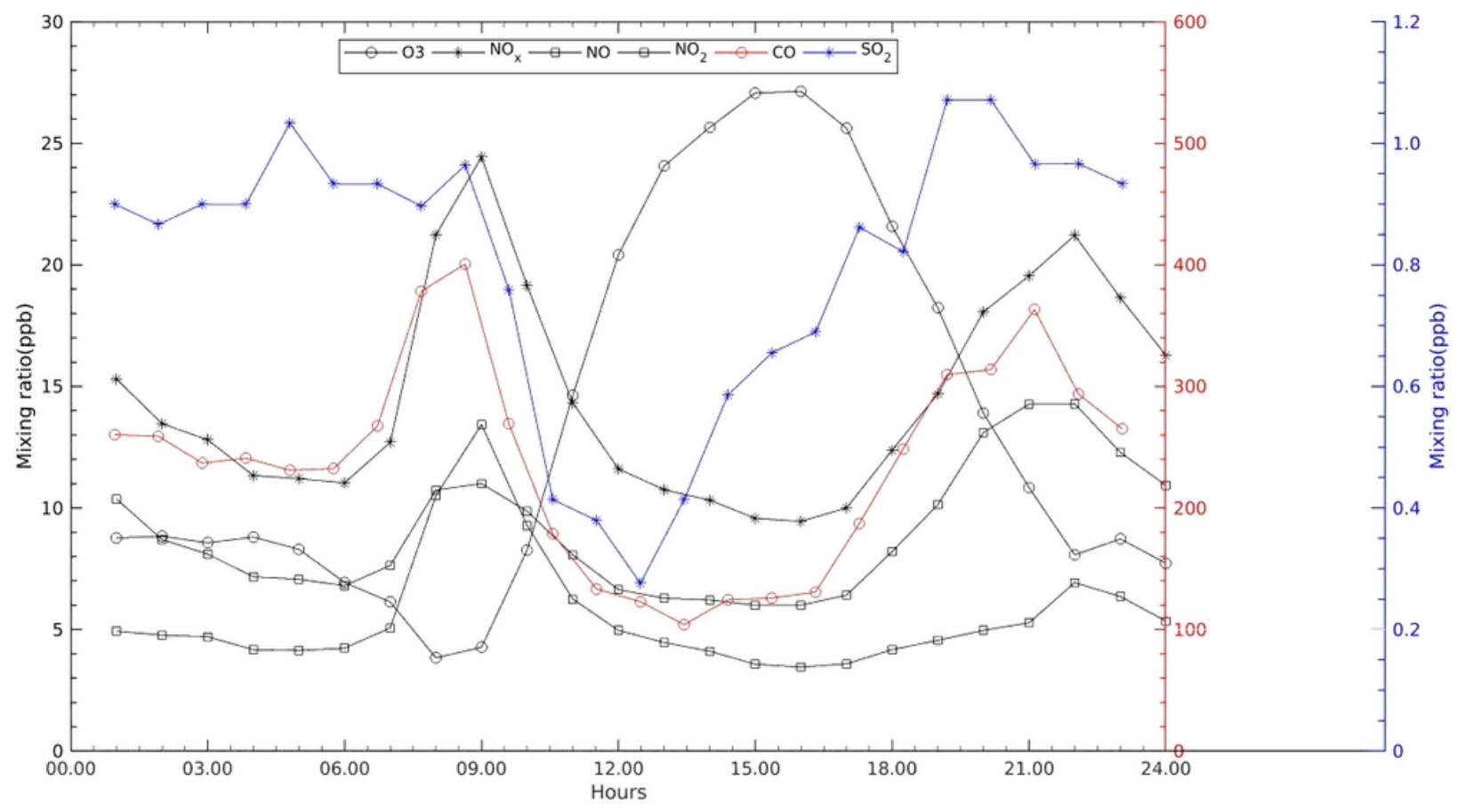

Figure 7 


\section{(a) Temperature}

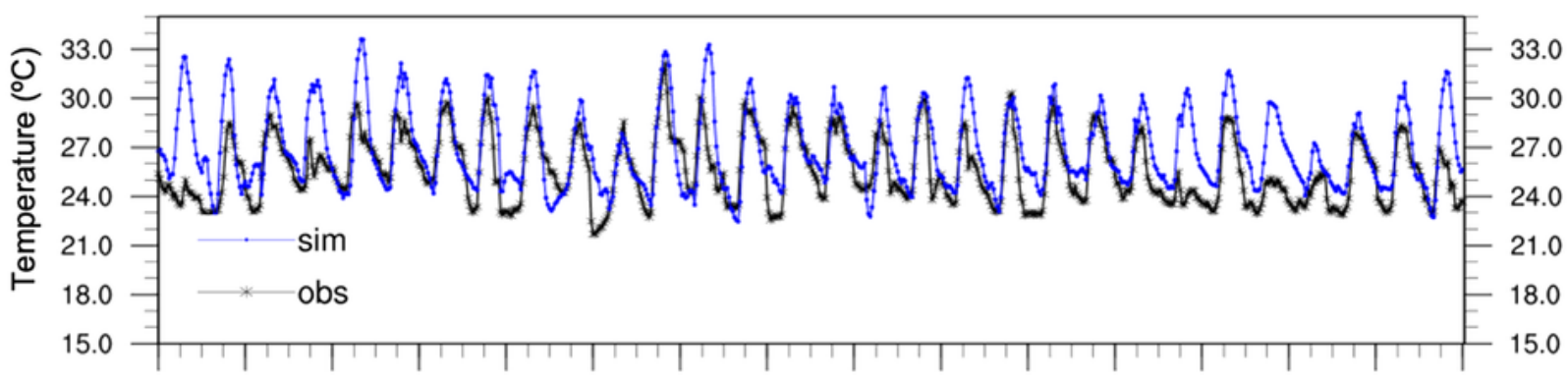

(b) Wind speed

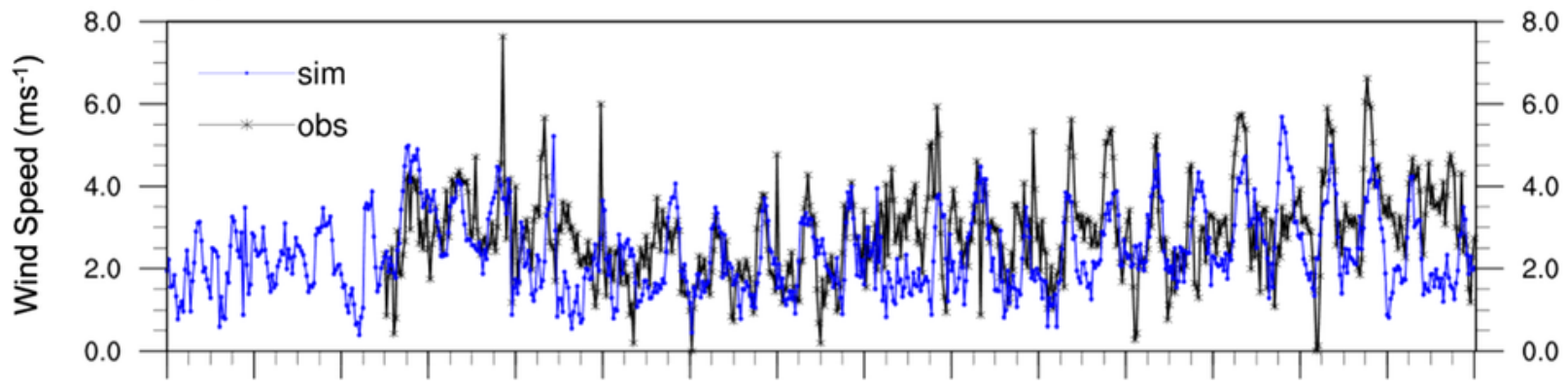

(c) Planetary boundary layer height (PBLH)

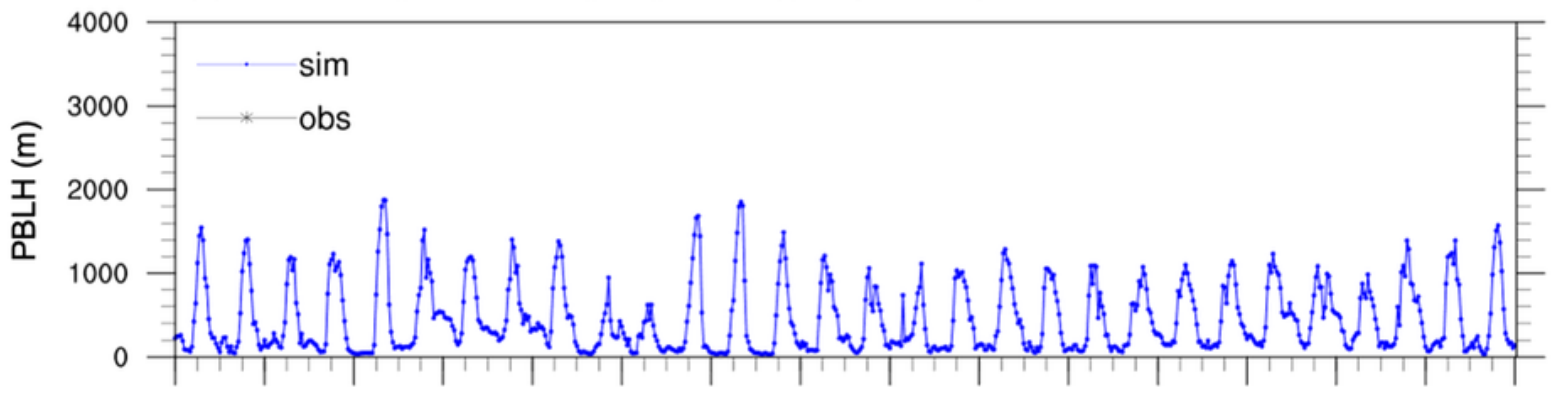

(d) Isoprene concentration

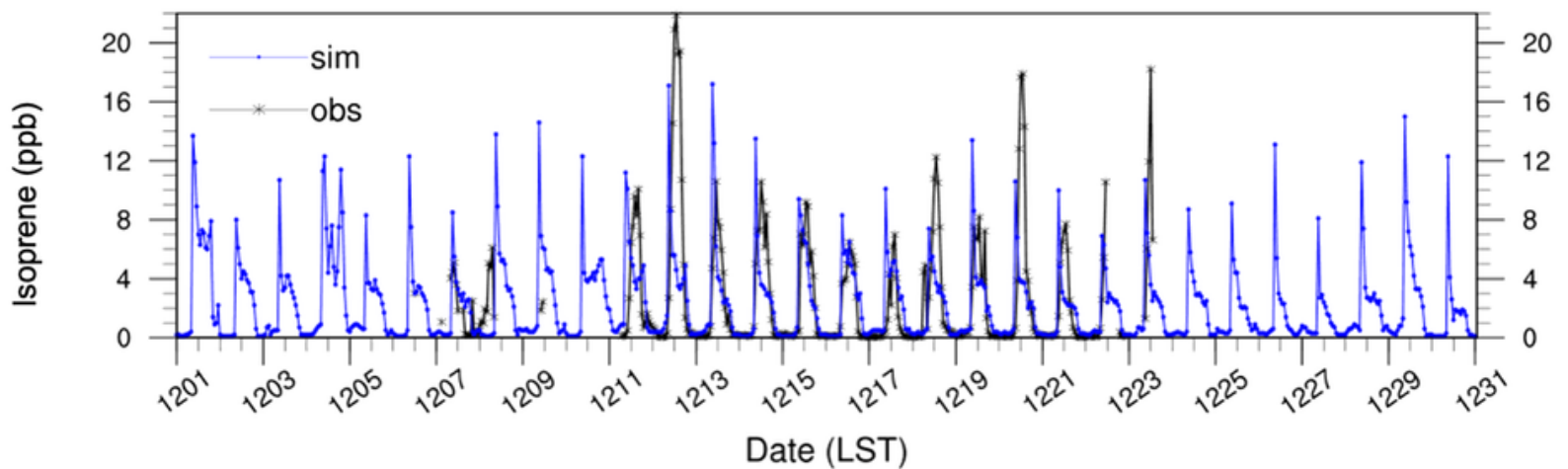

Figure 8

Comparison plot of observation and WRF-CMAQ output for December 2016 for (a) temperature, (b) wind speed, (c) PBLH, (d) isoprene concentration. 
(a) ISOP - $1100 \mathrm{LT}$

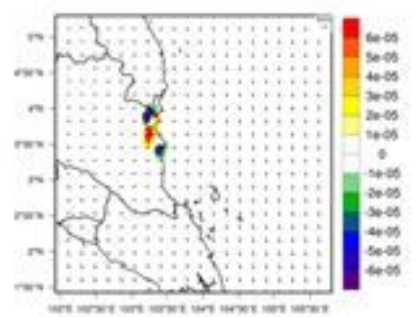

(d) ISOP - $2100 \mathrm{LT}$

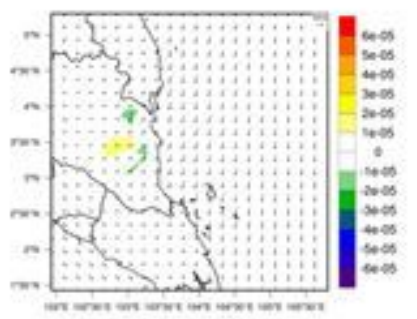

(b) ISOP - 1400 LT(c) ISOP - 2000 LT
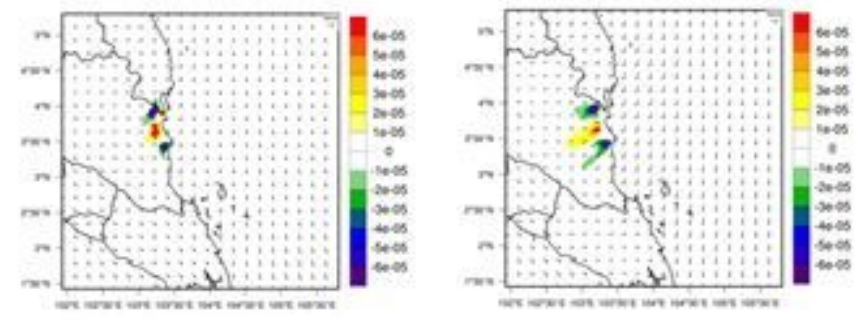

(e) $03-1400 \mathrm{LT}$

(f) $03-2000 \mathrm{LT}$

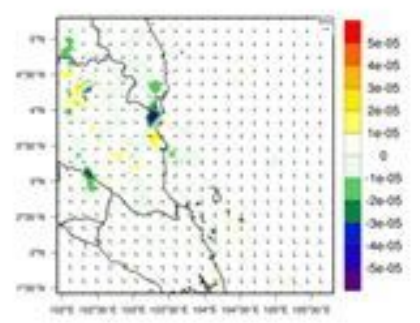

\section{Figure 9}

Difference between land use 2016 and 2000 for monthly-averaged hourly distribution of emission over the 3rd domain in December 2016: (a-d) Isoprene (ppm) at 1100, 1400, 2000, 2100 LT, (e-f) Ozone (ppm) at 1400 and 2000 LT.

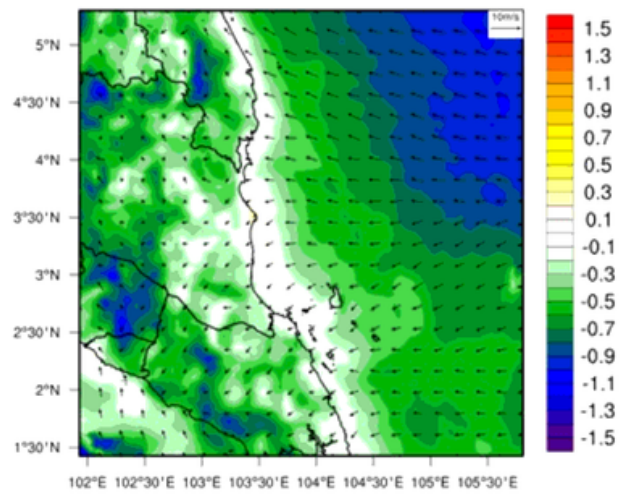

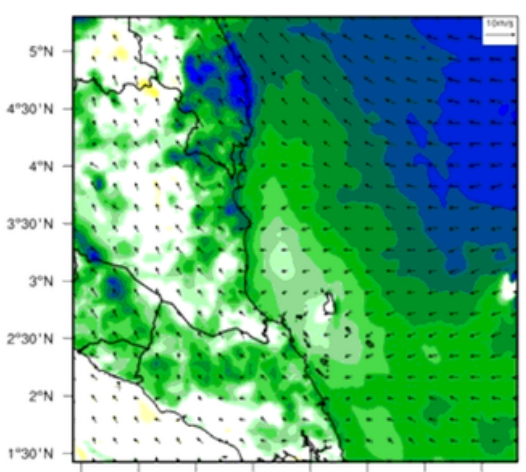

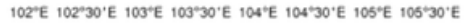
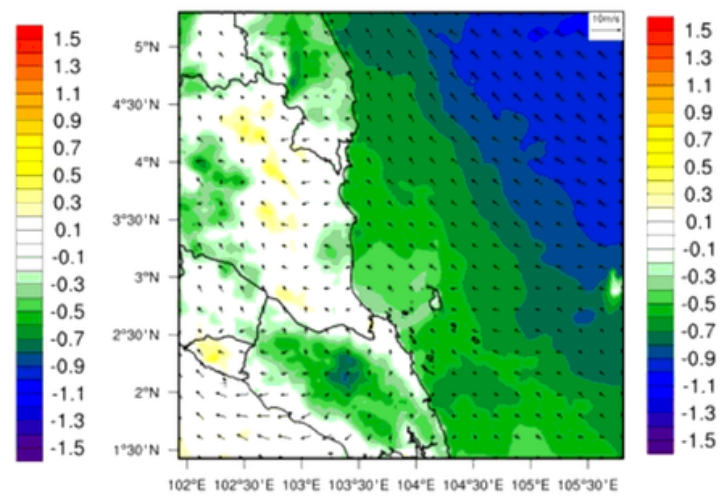

Figure 10

Difference between Jan 2017 and Dec 2016 for monthly-averaged hourly distribution of 2-meter temperature over the 3rd domain at (a) 1100, (b) 1400, (c) 2000 LT. 
Isoprene flux

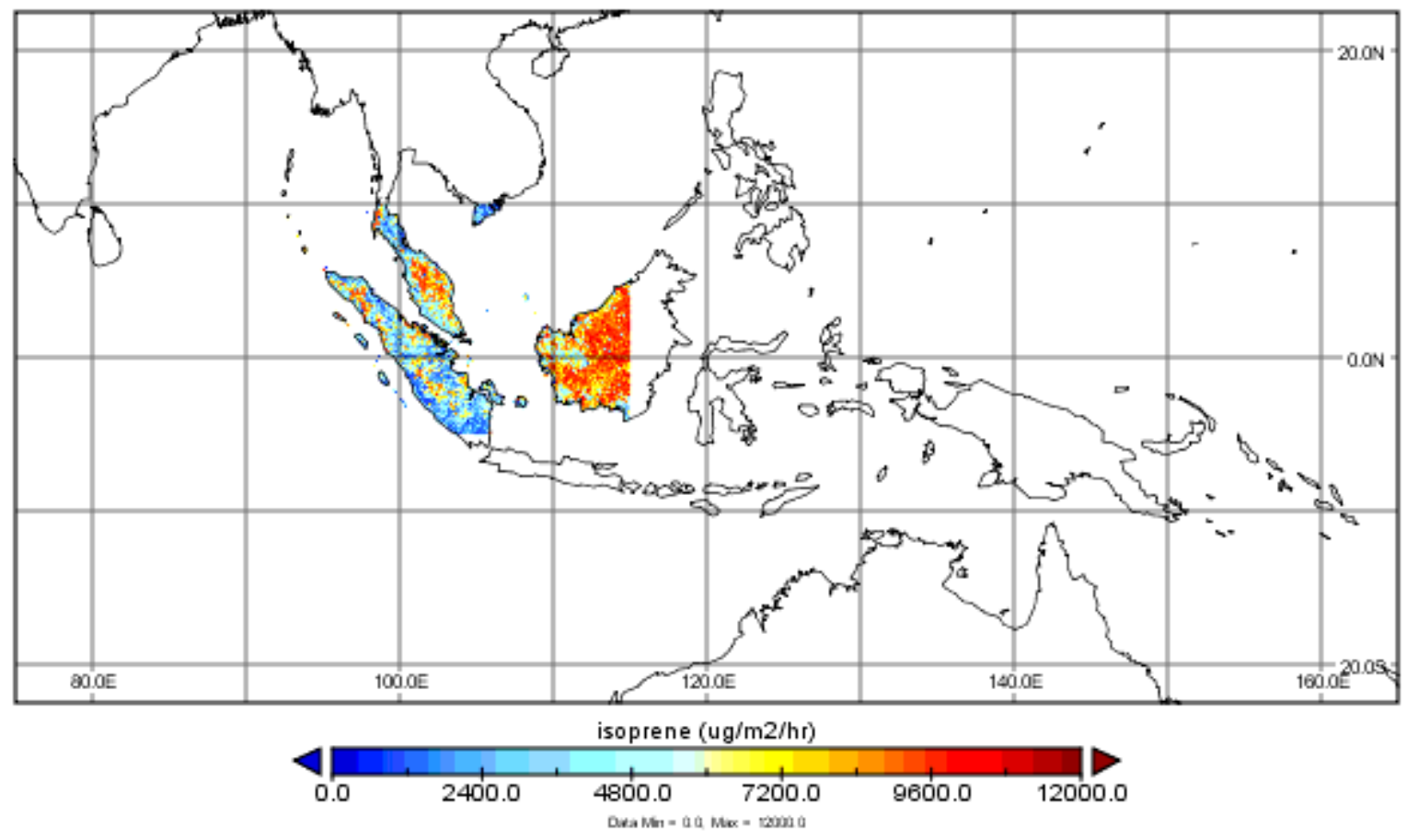

\section{Figure 11}

The potential importance to air quality of new palm oil plantations near cities. (Isoprene emission rates of isoprene expressed in $\mu \mathrm{g} \mathrm{m-2} \mathrm{h-1} \mathrm{over} \mathrm{the} \mathrm{Sungai} \mathrm{Miang,} \mathrm{Pekan} \mathrm{Palm} \mathrm{Oil} \mathrm{Plantation} \mathrm{(in} \mathrm{box)} \mathrm{in}$ December 2016 calculated by MEGAN) 